\title{
Resistance to Multilateral Influence on Reform: The Political Backlash against Private Infrastructure Investments
}

\author{
Witold J. Henisz and Bennet A. Zelner ${ }^{* * *}$ \\ The Wharton School \\ University of Pennsylvania \\ Philadelphia, PA 19104-6370 \\ henisz@,wharton.upenn.edu \\ 215-898-0788 \\ and \\ McDonough School of Business \\ Georgetown University \\ Washington D.C. 20057-1147 \\ zelnerb@georgetown.edu
}

202-687-6087

\begin{abstract}
:
Coercive isomorphism is a prominent source of institutional change. The literature to date has emphasized how actors that are powerful and legitimate (e.g., a national government) may coerce the adoption of reforms by dependent actors (e.g., state governments and other organizations whose activities are governed by the federal government). We observe that an actor's power alone may be sufficient to promote reform, regardless of the actor's legitimacy. However, such reforms are more susceptible to subsequent change than are those that emerge from processes not subject to the influence of external actors whose sway derives from their power alone. We develop and test our arguments in the context of the worldwide electricity provision industry by analyzing countries' adoption of reforms in response to conditional lending practices by multilateral organizations such as the World Bank and the IMF. We find that reforms adopted in response to coercive pressures exerted by these organizations encounter much greater resistance, and that the incidence of financial and economic crises, the absence of checks and balances in established political institutions, and the inexperience of investor coalitions dramatically increase the predicted level of resistance.

World Bank Policy Research Working Paper 3690, September 2005

The Policy Research Working Paper Series disseminates the findings of work in progress to encourage the exchange of ideas about development issues. An objective of the series is to get the findings out quickly, even if the presentations are less than fully polished. The papers carry the names of the authors and should be cited accordingly. The findings, interpretations, and conclusions expressed in this paper are entirely those of the authors. They do not necessarily represent the view of the World Bank, its Executive Directors, or the countries they represent. Policy Research Working Papers are available online at http://econ.worldbank.org.

* This paper was prepared as part of the research program on Industrial Organization Policy for Development at the Development Research Group of the World Bank, under the direction of Ioannis Kessides.

** Both authors contributed equally and list their names alphabetically on joint work. We thank The GE Fund; The Reginald H. Jones Center for Management Policy, Strategy, and Organization; The Mack Center for Technological Innovation; and the Tysoe Family Dean's Leadership Fund and Dean's Faculty Research Support Fund of the McDonough School of Business for their generous financial support. We acknowledge the research assistance of Seth Abramowitz, Jack BeVier, Michael Brownfield, Danielle Demianczyk, Indranil Guha, Matthew Heron, Sophie Hoas, Russell Jame, Srividya Jandhyala, Eugene Kakaulin, Anna Kalenchits, Hee Young Kim, Eliezer Klebanov, Michele Konrad, Dan Matisoff, David Morales, Kyu Oh, Ayokunle Omojola, Daniella Polar, Brett Shaheen, Jack Sheu, Bartlomiej Szewczyk, Zhen Tao, Ozveri Teymur and Anna Yen.
\end{abstract}




\title{
Resistance to Multilateral Influence on Reform: The Political Backlash against Private Infrastructure Investments
}

\begin{abstract}
:
Coercive isomorphism is a prominent source of institutional change. The literature to date has emphasized how actors that are powerful and legitimate (e.g., a national government) may coerce the adoption of reforms by dependent actors (e.g., state governments and other organizations whose activities are governed by the federal government). We observe that an actor's power alone may be sufficient to promote reform, regardless of the actor's legitimacy. However, such reforms are more susceptible to subsequent change than are those that emerge from processes not subject to the influence of external actors whose sway derives from their power alone. We develop and test our arguments in the context of the worldwide electricity provision industry by analyzing countries' adoption of reforms in response to conditional lending practices by multilateral organizations such as the World Bank and the IMF. We find that reforms adopted in response to coercive pressures exerted by these organizations encounter much greater resistance, and that the incidence of financial and economic crises, the absence of checks and balances in established political institutions, and the inexperience of investor coalitions dramatically increase the predicted level of resistance.
\end{abstract}




\section{Introduction}

Political actors that coerce dependent actors to undertake institutional change are often assumed to succeed on account of both their power and legitimacy. ${ }^{1}$ Accordingly, reforms (of policies or practices) adopted in response to legal coercive influences (such as reforms adopted by state governments in response to pressure from the central government) are often assumed to enjoy an initial positive evaluation by actors in the adopting organization, which confers "morally-based" legitimacy (Suchman, 1995) on these elements and allows them to survive for a sufficiently long period to undergo the process of institutionalization and attain "cognitivelybased legitimacy" (or “taken-for-grantedness” (Suchman, 1995)).

Legitimacy is not, however, a necessary precondition for effective coercion; power alone is sufficient (Weber, 1978; DiMaggio and Powell, 1983). Powerful actors may therefore be considered illegitimate by the dependent actors that they coerce to adopt reforms, and reforms adopted in response to coercion by such actors may thus be deemed illegitimate, increasing the probability that actors in society will resist their adoption and institutionalization (Weber, 1978: 33-38).

A substantial body of work has considered how coercive pressures may generate the formal adoption of a reform but a decoupling of the actual behavior of actors from the "myth and ceremony" of compliance with the letter of that reform (Meyer and Rowan, 1977; Westphal, Gulati, and Shortell, 1997; Staw and Epstein, 2000). In contrast, only two smaller bodies of work consider, as we do, the determinants of resistance to formal adoption that at least initially generates changes in actual behavior. The literatures on social movements (Barkan, 1984;

\footnotetext{
${ }^{1}$ For important exceptions, see Stryker's (1994) examination of the impact of the introduction of science into law on the legitimacy of law and Patashnik's (2003) qualitative study of policy-feedback effects.
} 
Griffin, E., and Rubin, 1986; Kerbo and Shaffer, 1992) and procedural justice (Tyler, Rasinski, and McGraw, 1985; Tyler, 1994) have considered the mechanisms that individuals (or interest groups representing like-minded individuals) use to resist reforms adopted primarily due to the influence of powerful external actors who lack legitimacy. We build on these micro-level studies by using neoinstitutional theory to analyze the conditions under which macro-level (i.e., countryor organization-level) reforms adopted in response to such influence are likely to face resistance that threatens their survival.

We consider the specific context of reforms intended to transfer (some portion of) ownership, control and operation of state-owned assets to private (and often foreign) corporations, in response to the influence of the World Bank, the International Monetary Fund and other multilateral lenders. While 92 countries adopted such reforms in1985-1999, resulting in the transfer of over one trillion dollars of assets to private ownership (in 60 countries transfers accounted for more than 5 percent of gross domestic product) (Brune, Garrett, and Kogut, 2004; Kogut and Macpherson, 2004a), these countries frequently encountered substantial resistance both at the time of reform adoption (Walton and Ragin, 1990) and subsequently (Henisz and Zelner, 2005).

Organized domestic interest groups that are adversely affected by market-oriented reforms initiate such resistance and, in an effort to capture policymakers' limited attention (Kingdon, 1984), attempt to mobilize broader segments of society by framing the reforms as foreign and illegitimate (Henisz and Zelner, 2005). The ultimate target of such resistance is the repeal of the reforms. However, disaffected interest groups often initially target narrow elements of the reform or specific investors whose activities are governed by such reforms, and governments may respond by reversing elements of the reform or with adverse actions against 
only certain investors (or inaction by failing to honor policy terms) as well as across-the-board policy revision or repeal.

Several conditions affect the incidence and success of resistance efforts. Resistance increases dramatically in periods of financial or macroeconomic crisis, when disaffected interest groups can frame current events as evidence of the adverse distributive consequences of marketoriented reforms. In contrast, resistance diminishes with both time (Oliver, 1991) and the level of checks and balances in a country's established political institutions (Henisz and Zelner, 2005). The efficacy of resistance efforts faced by individual investor coalitions can also vary: more experienced coalitions, or those that have greater influence over domestic policymakers, may be better able to avoid inimical policy changes and government disputes in the first place.

Our findings contribute to the literature on institutional change by empirically identifying the conditions under which external coercion generates reforms that eventually become institutionalized, and those conditions under which such reforms face sufficient resistance to undermine their stability. They also contribute to the burgeoning literature on the efficacy of multilateral lenders' "conditionality" policies, which require borrowing countries to adopt market-oriented reforms. While the World Bank and International Monetary Fund are increasingly aware of the importance of politics as well as economics for the success of their lending programs, our theoretical arguments about the determinants of resistance and empirical results that support them suggest that multilateral lenders should place greater weight on neoinstitutional theory broadly defined.

\section{Institutions: Established and Emergent}

According to the neoinstitutional perspective in organization theory, an institution's defining characteristic is "legitimacy" attained on "cognitive" grounds. Legitimacy refers to "the 
generalized perception or assumption that the actions of an entity are desirable, proper, or appropriate within some socially constructed system of norms, values, beliefs and definitions" (Suchman, 1995: 574). "Cognitively-based legitimacy" (Suchman, 1995: 579-81) derives from an entity's widespread, implicit acceptance — propriety by assumption — resulting from the longterm process of "institutionalization" (Zucker, 1987).

Members of society do not actively assess institutions, which have come to possess "a reality of their own, a reality that confronts the individual as an external and coercive fact" (Berger and Luckman, 1967). This "taken-for-grantedness" imbues institutions with high resistance to change (Zucker, 1977); indeed, an institution's very "essence" is one of “permanence" (Suchman, 1995: 584).

Reforms adopted in response to multilateral influence necessarily lack cognitively-based legitimacy (Suchman, 1995: 582) because the social process of institutionalization is a lengthy one. Accordingly, investors operating whose activities are governed by such newly introduced policies and organizational entities are likely to encounter greater resistance than are their counterparts whose activities are governed by policies and organizational entities deemed legitimate. In order to distinguish these two classes of governance structures, we subsequently refer to the former as "emergent institutions" and the latter as "established institutions."

Unlike established institutions, whose consequences, procedures and structural type (Suchman, 1995: 579-81) are largely beyond normative evaluation, emergent institutions' consequences, procedures and structural type are explicitly subject to such evaluation by actors in society. If positive, this evaluation may imbue an emergent institution with "morally-based" legitimacy (Suchman, 1995: 579-81) and consequently decrease the resistance faced by investors operating under that institution; a negative evaluation, in contrast, may trigger resistance. 
In the case of emergent regulative institutions, the mechanisms of resistance operate through the policymaking process, wherein interest groups that vary in their level of organization (Olson, 1965; Lowi, 1969; Wilson, 1980; Denzau and Munger, 1986) attempt to influence political actors seeking to retain office (Kingdon, 1984; Lau, Smith, and Fiske, 1991) within the constraints imposed by a formal policymaking structure (Gilligan and Krehbiel, 1980; Weingast, 1981; Weingast and Moran, 1983; McNollGast, 1987; Weingast and Marshall, 1988; Tsebelis, 2003). The primary agents of change are the organized interest groups (Olson, 1965; Stigler, 1975; Peltzman, 1976; Becker, 1983) that are most dissatisfied with how the emergent institution accommodates their interests (Holm, 1995; Sjöstrand, 1995; Greenwood and Hinings, 1996; Seo and Creed, 2002), and the most common source of dissatisfaction is the emergent institution's distributional consequences (March and Simon, 1958).

Because these primary change agents are often insufficiently powerful on their own to move the issue of change onto the limited policymaking agenda (Kingdon, 1984; Hilgartner and Bosk, 1988), they attempt to enlist the support of a broad range of "secondary" groups — other organized interest groups and diffuse, unorganized groups whose members are either marginally affected or unaffected by the emergent institution - that together are capable of capturing policymakers' limited attention (Lipsky, 1968; Schumaker, 1975; Jenkins and Perrow, 1977; Denzau and Munger, 1986; Baumgartner, 2002; Baumgartner and Mahoney, 2002). The core techniques that primary change agents use to mobilize secondary groups revolve around “framing" (Benford and Snow, 2000) the emergent institution's consequences, procedures or structural type (Suchman, 1995: 579-81) as conflicting with pre-existing "cultural preoccupations and political biases" (Hilgartner and Bosk, 1988: 63; McFarland, 1991). 


\section{Resistance to Emergent Institutions}

\subsection{Foreign Coercion}

A substantial body of work argues that a powerful, legitimate actor's sanction of an emergent institution facilitates its adoption by dependent actors (Tolbert and Zucker, 1983), ${ }^{2}$ but the issue of the resistance to the emergent institution's adoption has received considerably less attention. Tolbert and Zucker (1983) write that new elements of formal structure,

“...once legitimated by higher level organizations, through legal mandate or other formal means, [are rapidly incorporated by] dependent organizations. This adoption is seldom problematic when the elements have high face validity and there is common agreement concerning their overall utility. However, under certain conditions, strong resistance can develop." (Tolbert and Zucker, 1983: 27)

${ }^{2}$ The early studies examining the role of such external actors on the adoption of new formal institutional structures focused on the public sector. For example, building on (Benson, 1975; Rowan, 1982) argues that where the outcome of the process of policymaking among state-level legislatures, regulatory agencies and interest groups reflects a state of "balance" or consensus, local-level public sector actors are more likely to adopt and retain newly introduced state-level formal structures. Tolbert and Zucker (1983) find more rapid adoption of civil service procedures by cities in American states that mandated them and that directed the process through a single administrative source. Westney (1987) highlights the role of the Japanese state in the Meiji period in diffusing organizational models through that country's public sector. Later work demonstrated that similar coercive pressures may be generated by the state on private actors (Cole, 1985; Singh, Tucker, and House, 1986; Baron, Jennings, and Dobbin, 1988; Edelman, 1990; Baum and Oliver, 1992; Dobbin, et al., 1993; Dobbin, 1994; Sutton and Dobbin, 1996; Ruef and Scott, 1998; Strang and Bradburn, 2001; Simons and Ingram, 2003), by informal institutional pressures on private sector actors (Dacin, 1997) or by higher-level private actors on their lower-level counterparts (Levitt and Nass, 1989; Fligstein, 1990; Haveman, 1993a; Haveman, 1993b; Podolny, 1993).

More closely related to our international empirical context, researchers have also demonstrated the importance of political actors in other countries for the decisions of political actors in a focal country. Strang (1990) finds that a supportive 1960 United Nations Declaration had a strong positive impact on the subsequent diffusion of decolonization. Membership in International Labor Organization conventions enhances subsequent welfare spending (Strang and Chang, 1993) and UNESCO membership increases the probability of founding a formal science bureaucracy (Finnemore, 1993). U.S. pressure in the form of trade sanctions stimulated the adoption of intellectual property provisions by developing countries (Sell, 1995). Powerful external actors also influence the incidence of currency crises (Glick and Rose, 1998), the adoption of policies to protect the environment (Frank, Hironaka, and Schofer, 2000a; Frank, Hironaka, and Schofer, 2000b) and the adoption of quality certification (Guler, Guillén, and Macpherson, 2002). 
The authors pose as examples of such conditions a lack of consensus on the value of a new element of formal structure and the presence of strong opposing coalitions or interest groups, but they "do not explore the conditions underlying such resistance" (Tolbert and Zucker, 1983).

We focus on the condition where no such legitimation occurs, and the powerful actor coerces the adoption of an emergent regulative institution on the basis of its power alone (Weber, 1978; DiMaggio and Powell, 1983). Compared to the emergent regulative institutions that the dependent actor adopts of its own accord, the "coerced" emergent institution in this case is less likely to make the transition to established institution (i.e., become institutionalized), and investors whose activities are governed by this entity are more likely to encounter resistance from disaffected interest groups - the primary change agents discussed above—and the secondary groups that the primary groups mobilize.

Inconsistency of institutional attributes. Oliver (1991) provides the most complete treatment of this topic to date, arguing that the degree of an adopting body's dependence on the coercive actor, the strength of legal sanctions for non-compliance, uncertainty in the adopting body's environment, and consistency between the emergent institution and established institutions in this environment all determine the likely degree of resistance. Of these attributes, the last one - consistency - is especially germane in the current context. The domestic policymaking process, when not subject to external coercive influences, typically produces emergent institutions whose consequences, procedures and structural type are isomorphic to those of established institutions already deemed legitimate. During periods of crisis, however, domestic actors are more likely to suppress objections they would otherwise voice in the pursuit of an expedient solution (Nelson, 1990; Alesina and Drazen, 1991; Fernandez and Rodrik, 1991; Drazen and Grilli, 1993; Williamson, 1993) and defer to the preferences of external actors 
promising to deliver such a solution. As a result, externally-coerced emergent institutions are less likely to be isomorphic to established institutions possessing legitimacy. Indeed, one of the main techniques that primary change agents use to mobilize secondary groups against an emergent institution is to demonstrate the entity's inconsistency with established reference points (Henisz and Zelner, 2005).

National identity and legitimate adoption processes. In addition to the likelihood that a coerced regulative structure's consequences, procedures or structural type will differ from those of established institutions, the very process of such an entity's adoption in response to an external organization whose influence derives from its power alone increases its susceptibility to change. A large body of research in the field of political sociology emphasizes the power of national identity and points to the consistency of a regulative institution's formation process with domestic procedural norms as a key determinant of the institution's legitimacy, and implicitly its survival. ${ }^{3}$ In a classic piece on macro-level political regimes, Bendix (1978) notes that the modern nation-state derives its legitimacy from the sanction of the people, in contrast to the European kings of the sixth through 16th century, who sought to attain legitimacy (and thus retain power) through the external sanction of organized religion ${ }^{4}$. Bendix argues in particular that the extent to which citizens regard the process by which their preferences are aggregated into policy as legitimate determines the survival of modern regimes. Thus, the greater the shared sense of identity and community among the people of a nation, the greater the stresses and

\footnotetext{
${ }^{3}$ Similar arguments are made at the organizational level by Fox-Wolfgramm, Boal \& Hunt (1998) who demonstrate the importance of consistency a proposed institutional change with actors' "cognitive schema or perception of their organization's central and distinctive attributes" (Elsbach and Kramer, 1996: 442) as a pivotal factor in determining the level of observed resistance by bank workers to regulatory reform.

${ }^{4}$ Specifically, Bendix (1978) argues that the ability of a monarchy to survive in a given polity depended on the king's ability to use the religious sanction to delegate authority to rule to an aristocracy without losing control either to elements of that aristocracy, other kings, or an alliance of both.
} 
turbulence its rulers are able to survive (Lipset, 1959). ${ }^{5}$ The prevalence of nationalism as an organizing force in the modern era (Meyer, et al., 1997) reduces the probability that emergent institutions introduced by foreign actors will be deemed legitimate and thus increases the resistance that investors operating whose activities are governed by such entities are likely to face.

International coercion and illegitimate adoption processes. At the same time, the organizational form of the nation-state faces increasing challenges to its power and authority by international political and economic actors (Riain, 2000; Guillén, 2001b). Despite evidence that nation-states retain substantial policy autonomy (Garrett, 2000), the scale and scope of international economic, political and social pressures that national governments now face is substantially greater than in previous decades. ${ }^{6}$

The most concrete and successful manifestation of the globalization of national policy environments has occurred among the member states of the European Union (Fligstein and Sweet, 2002; Padgett, 2003; Thatcher, 2004). Even in this extreme instance, however, substantial national resistance to convergence remains. ${ }^{7}$ Several authors highlight that even in the presence of common agreement on goals, principles and procedures (Steffek, 2003), the European Union (EU) will never enjoy the authority of national governments because (Hansen and Williams,

\footnotetext{
${ }^{5}$ For example, Razi (1987) argues that the fall of the Shah's regime in Iran was directly attributed to a "failure in the area of legitimacy and cannot be satisfactorily explained in terms of performance ... or class struggle" (p. 465). By failing to demonstrate independence from the dominant imperial power of the era (the United States), violating Iran's own Constitution and suppressing long-standing religious norms, the Shah eroded the legitimacy of his regime and set the stage for a rapid downfall embraced by almost all segments of the society included those who had benefited under his rule. Bienen (1991) tests this logic on a cross-national sample, showing that the prior duration of a given political regime is the best predictor of its continued survival suggesting that over time a polity develops not only an identification with a national community but also with a given political leadership or regime.

${ }^{6}$ See Guillén (2001a) for a recent interdisciplinary review of the globalization literature.

${ }^{7}$ For example, Busch (2004) chronicles the national heterogeneity in banking regulations that persists even in the face of explicit efforts to craft a single European capital market.
} 
1999; Horeth, 1999; Laffan, 2001) EU citizens lack the common identity, shared myths, beliefs and history that citizens of an individual country share (Cederman, 2001). ${ }^{8}$

A larger body of related qualitative work on cases other than that of the relatively successful European Union similarly emphasizes the importance of national identity and "ideational systems... comprised of values, beliefs and symbols" (Dobbin, 1993: 3) for understanding the differing responses of individual nation-states to similar external stimuli. Studies of the policy responses by France, Great Britain and the United States to the Great Depression (Dobbin, 1993), Central European countries' to pressure for fiscal austerity (Campbell, 1996) and Chile, Great Britain, France and Mexico's to the ascendancy of neoliberal economic policies since the 1970s (Fourcade-Gourinchas and Babb, 2002) all conclude that a given external stimulus interacting with a nation's distinct formal and informal national institutions can generate radically different national policy outcomes. ${ }^{9}$ Spicer, McDermott and Kogut (2000) present a related thesis, arguing that the policy goal of efficient reallocation of productive assets within an economy, which may be best accomplished through the financial system in well-developed capitalist systems such as the United States, should occur through gradualist negotiated public-private bargaining in Central European and post-Communist societies.

The insight that a country's ideational systems influence the characteristics of the policies that it adopts implies that a given externally-coerced policy's "fit" with a particular country-

\footnotetext{
${ }^{8}$ As a result, the crisis of legitimacy that characterizes EU governance and limits policy convergence is not a short-term problem that can be addressed at the next ministerial conference but rather a long-term and fundamental challenge to the expressed goal in the Treaty of Rome of establishing an "ever closer union."

${ }^{9}$ Guillén (2001b) extends this logic down to the level of organizations within countries and the heterogeneity in practices that managers in Argentina, South Korea and Spain introduced in response to the homogeneous pressure of globalization.
} 
and thus the policy's resistance to change-also depends on such systems. Multilateral lenders have long recognized this latter point: “...the commitment of the Borrower to implementation is... one of the key factors affecting project performance" (Heaver and Israel, 1986:1). ${ }^{10}$ Indeed, as early as 1959, Per Jacobsson, the Managing Director of the International Monetary Fund, asserted that "such programs can only succeed if there is the will to succeed in the countries themselves" (James, 1996: 109). ${ }^{11}$

For just as long, however, multilateral lenders and borrowing countries have disagreed on the meaning of and best means to encourage local "ownership" of required reforms (Helleiner, 2000; Boorman, 2001; Boughton, 2003; Khan and Sharma, 2003; Drazen and Isard, 2004; Kikeri and Nellis, 2004), debating whether ownership means that either loan recipients “...drive the process... [including] the planning, the design, the implementation, the monitoring and the evaluation" (Helleiner, 2000: 2) , "do what [lenders] want them to do but... voluntarily" (Helleiner, 2000: 2), or something in between.

To the extent that multilateral lenders are unwilling to abdicate all aspects of program management to the borrower out of fear of the inherent conflict between the incentives of lender and borrower in the disposition of loan money (Mansuri and Rao, 2004), multilateral lending necessarily includes some degree of external coercive pressure. A growing literature on the implementation of multilateral policy prescriptions, funded largely by the multilateral institutions themselves, acknowledges this pressure and uses economic or political analysis to identify mechanisms that might reduce such potential deleterious effects of the incentive conflict—or “agency problem"—on policy performance.

\footnotetext{
${ }^{10}$ Quoted in Morrow (1999:1).

${ }^{11}$ Quoted in Boorman (2001)
} 
A much larger set of studies offers a normative critique of existing multilateral conditionality practices, arguing that the very existence of such a conflict undermines the rationale for conditional lending in the first place. In moral terms, writes Buira, conditionality is viewed "at best" as a "form of paternalism, by which a country is guided toward its own good, rather like a parent or a teacher guides a child, in its own best interests, [while] at worst, conditionality implies the imposition on a country of an alien policy agenda that contains elements that are not necessary... and may not be in the country's best interest." (Buira, 2003). Feldstein summarizes the more general moral argument against the practice of conditionality with reference to the International Monetary Fund (IMF), writing that:

"The fundamental issue is the appropriate role for an international agency and its technical staff in dealing with sovereign countries that come to it for assistance. It is important to remember that the IMF cannot initiate programs but develops a program for a member only when that country seeks help. The country is then the IMF's client or patient, but not its ward. The legitimate political institutions of the country should determine the nation's economic structure and the nature of its institutions. A nation's desperate need for short-term financial help does not give the IMF the moral right to substitute its technical judgments for the outcome of the national political process (1998: 27).

Most recently, Joseph Stiglitz, writing after his experience as a Senior Vice President and later Chief Economist of the World Bank, expresses "a concern that the way changes were effected undermined democratic processes..." (Stiglitz, 1999: 591).

In trying to address the issue of why multilateral lenders would impose policies that undermine lenders' socio-political stability and economic ability to repay their loans, a number 
of contributions to this literature invoke the notion of identity, just as in the political sociology literature. ${ }^{12}$ Simply put, multilateral lenders are not part of the national political system of the lending countries, and exercise their policy influence through a process distinct from the regular national policymaking process. Because the resultant policies are inconsistent with other laws or statutes, they contravene the powerful psychological forces of identity and nationality, and are more vulnerable to resistance efforts (Jasper and Poulsen, 1993).

On this basis, we propose that emergent institutions whose adoption are more heavily influenced by foreign coercive pressures are less likely to be perceived as legitimate, and investors whose activities are governed by these entities are more likely to encounter resistance.

Hypothesis 1: Investors whose activities are governed by an emergent institution whose adoption is associated with foreign coercive pressures are more likely to encounter resistance.

\subsection{The Aggravating Role of Crises}

The efficacy of the techniques that disaffected interest groups use to influence public opinion, and thus increase the resistance faced by investors whose activities are governed by an emergent institution, are greater during times of economic crisis. Crises provide powerful images that these groups my use as "focusing events" (Kingdon, 1984: 106) to develop (or bolster) an "injustice frame" (Gamson, Fireman, and Rytina, 1982) based on an alleged causal link between the emergent institution's foreign origins and prevailing domestic adverse economic

${ }^{12}$ A somewhat related line of critique explored forcefully by (Babb, 2003; Kogut and Macpherson, 2004b; Kogut and Spicer, 2004) lies in the professional identity of multilateral lenders in the economics and financial sectors. Such professional training and prior experience may pose challenges in accepting the importance of institutional context, the psychological power of identity, and the political force of nationalism and fear. 
conditions. ${ }^{13}$ Such a frame serves as an effective tool for enhancing the cohesion of the existing coalition and enfranchising secondary groups whose members did not previously regard change in the emergent institution as a salient political issue (Andrews, 1997; Hoffman, 1999; Seo and Creed, 2002).

Other actors may assist organized interest groups in their campaign for change during a crisis. "Political entrepreneurs" including incumbent politicians, opposition politicians and nongovernmental organizations (NGOs) may exploit crisis events in order to boost their own popular support (Jones, 1978; Schneider and Teske, 1992; Cox and McCubbins, 1993), especially during elections or other periods of political contention. McFarland's cyclical theory of interest group politics (1991) as well as the broader macroeconomic literature on political business cycles, which emphasizes how political actors may opportunistically manipulate policy levers under their control for the purpose of electoral gain (Nordhaus, 1975; Rogoff and Sibert, 1988; Alesina, 1989), are both illustrative. Media organizations with their own political agenda may play a role as well, especially in enfranchising diffuse, previously unorganized groups (Weingast, 1981; Levy and Spiller, 1994). Moreover, economic actors that control resources whose value is reduced by the crisis or the policies promoted by multilateral lenders (North, 1990; Landes, 1998), or who are otherwise adapted to prior circumstances (Ingram, 1998), may also join the

\footnotetext{
${ }^{13}$ An injustice frame uses the contrast between the conditions of one entity (e.g., foreign investors) and another (e.g., local consumers) to reinforce citizens' preexisting notions that the party doing relatively well attained its status unfairly or illegitimately. Three injustice frames are particularly relevant for opponents of market-oriented reforms whose adopted is heavily influenced by multilateral actors: (1) the contrast between the losses incurred by domestic "victims" and the relative well-being of foreign investors insulated by the emergent regulative institution (Gamson, Fireman, and Rytina, 1982); and (2) the relative lack of initial public debate about the design of the emergent institution (Mlcoch, 1998; Kogut and Spicer, 2002); and (3) the accusation that the policymakers in the country adopting the market-oriented reform were violating an implicit guarantee of protecting the welfare of its population particularly the poor consumers whose prices were frequently substantially increased in an attempt to remove economically inefficient cross-subsidization (Krieger, 1963; Berkowitz and McQuaid, 1978; Skocpol and Amenta, 1986; Quadagno, 1987).
} 
coalition of resistance. Even members of the original coalition supporting the adoption of the emergent institution are more likely to defer or compromise if the cost of delayed resolution is high and change in the emergent institution—including its elimination —appears to be an expedient solution (Nelson, 1990; Alesina and Drazen, 1991; Fernandez and Rodrik, 1991; Drazen and Grilli, 1993; Williamson, 1993).

Crisis conditions thus improve the ability of organized interest groups seeking change in an externally-coerced emergent institution to obtain such change. Indeed, the conditions that a crisis creates may play the pivotal role in determining whether such a group is able to secure major (or punctuated) change rather than incremental (or creeping) change, which is typically more common in the policymaking arena (Astley, 1985; Romanelli and Tushman, 1994; Jones, Baumgartner, and True, 1998).

Hypothesis 2: Investors whose activities are governed by an emergent institution whose adoption is associated with foreign coercive pressures are particularly likely to encounter resistance in times of financial or macroeconomic crisis.

\subsection{The Moderating Role of Vintage}

Although investors whose activities are governed by emergent institutions adopted in response to external coercive pressures are more likely to face resistance during a crisis, the timing of such a disruptive event is uncertain. Regardless of the other attributes that influence an investor's expected level of resistance, the very persistence of an emergent institution reduces resistance as the entity necessarily becomes "retrojected into consciousness in the course of [actors'] socialization" (Berger and Luckman, 1967: 60-61)" through the long-term process of institutionalization. 
Hypothesis 3: Investors whose activities are governed by an emergent institution whose adoption is associated with foreign coercive pressures are less likely to encounter resistance as the vintage of that institution increases.

\subsection{The Moderating Role of Established Political Institutions}

In countries whose formal upper-level political institutions include multiple checks and balances, interest groups seeking a wholesale or investor-specific policy revision or reversal must secure the agreement of multiple policymakers representing non-overlapping interests. Policymakers choose issues to address based not only on the political benefits that they expect to enjoy from "solving" an issue through policymaking, but also the "cost" that they must incur in terms of the time and effort that such policymaking requires. This cost depends largely on the configuration of the formal country-level political institutions-most prominently the internal structures of and relationships among the legislature, the executive branch, the judiciary and regulatory agencies - that govern the policymaking process (Amenta, Carruthers, and Zylan, 1992; Moe and Caldwell, 1994; McAdam, McCarthy, and Zald, 1996; Andrews, 2001).

Configurations that increase costs impede change, effectively mitigating interest group pressures for change (Tiller and Spiller, 1999; Tsebelis, 2003), while structures that reduce costs facilitate change, effectively increasing the potency of such pressures (Witt and Lewin, 2004).

Analysis of the effects of country-level institutional configurations on the incidence of policy change derives from the regulative pillar of neoinstitutional theory, including contributions from economic history (North and Weingast, 1989; North, 1990); formal political economy models (Dixit, 1996; Laffont, 1999); and qualitative evidence from recent policy shifts in infrastructure sectors (Spiller, 1993; Levy and Spiller, 1994) and elsewhere (Weingast and Moran, 1983; McNollGast, 1987; Gilligan, Marshall, and Weingast, 1989; Gely and Spiller, 
1990). Such institutions are usefully characterized in terms of checks and balances, including both de jure characteristics such as constitutional separation of powers as well as de facto characteristics such as the extent of partisan heterogeneity within and across branches of government. Institutional configurations with stronger checks and balances require agreement across a broader range of political actors to affect a shift in policy for a given level of societal pressure, increasing the effort required of any given political actor to change an emergent institution. In contrast, configurations that concentrate political power in the hands of a single actor facilitate change. Empirical evidence demonstrates the effects of institutional veto points on policy stability (Hallerberg and Basinger, 1998; Franzese Jr., 1999; Persson and Tabellini, 1999; Treisman, 2000; Henisz, 2004).

Hypothesis 4: Investors whose activities are governed by an emergent institution whose adoption is associated with foreign coercive pressures are less likely to encounter resistance as the strength of the effective checks and balances in the policymaking process increases.

\subsection{Investor Experience}

The conditions discussed above - the extent to which an emergent institution's adoption has been influenced by foreign actors, the emergent institution's vintage, the occurrence of a crisis and the strength of checks and balances - are all reform- and country-level attributes that influence the amount of resistance an investor is likely to encounter. However, investors vary in their susceptibility to such resistance.

All organizations confronted with the risk or reality of adverse change in an emergent institution face strong pressures to maintain legitimacy by acquiescing to such change (Oliver, 1991:160-161). Because the enforcement mechanism for emergent institutions is the coercive 
power of the state (Scott, 2001: 52), the penalties for noncompliance are both tangible and severe (Oliver, 1991:168). At the same time, the imposition of a new or modified institution intended to meet broader distributional demands significantly restricts an organization's discretion in key decisions such as "resource allocation, product or service selection, resource acquisition or organizational administration (i.e., hiring, compensation, promotion)" (Oliver, 1991: 166), and more generally chafes against the "technical activities and efficiency demands" (Seo and Creed, 2002:226) that support profitability. The prospect of substantial economic loss from conformity to the external mandates of the state thus creates strong internal pressures for organizations to resist change in emergent institutions.

An organization's information-based resources and capabilities affect its susceptibility to resistance (Boddewyn and Brewer, 1994). Given the difficulty of assessing complex, evolving socio-political conditions, managers that can look to their own past experience for an analogue to guide their current search for an organizational response or for accumulated learning (Baum and Ingram, 1998; Baum, Li, and Usher, 2000) are better equipped to make sound decisions under conditions of uncertainty. For example, Henisz and Delios (2001) find that prior experience in a specific country reduces the deterrent effect of cultural or market differences on a firm's decision to invest in the country. Lyles and Steensma argue that as a result of the wide diversity of emergent institutions governing infrastructure projects, investors' management of their relationship with the government is an important organizational capability and key "factor of success" in such projects (Lyles and Steensma, 1996: 70).

Hypothesis 5: The resistance encountered by a given investor declines in the experience of that investor in the national environment. 


\section{Methods}

\subsection{Data}

In order to test our hypotheses, we examine the investment history of 1,001 private electricity projects in 75 countries during the period $1989-2001$. These projects constitute the population of global private investment in electricity generation over this time period, as compiled by the Hagler-Bailly consultancy. In a small subset of countries (e.g., Germany, the United Kingdom and the United States), a substantial number of private investment projects predate our sampling period and are omitted from our analysis.

We augment the Hagler-Bailly dataset's information gathered from international, industry and local news reports available through various online databases. A large team of research assistants compiled this information and used it to code several of the variables described below. Validation of the coding of the dependent variable by the authors and a PhD student indicated a reliability of greater than 0.98 .

\subsection{Unit of Analysis}

Our hypotheses implicate independent variables at the country level ( $\mathrm{H} 2$ and $\mathrm{H} 4)$, the reform level (H1 and H3), and the investor level (H5). We address these multiple levels of analysis with a panel data set whose cross-sectional unit is an investment in a electricity generation facility by (a coalition of) investors, which is the most disaggregated of the three levels. Our unit of analysis is thus the investor coalition-country-year.

\subsection{Dependent Variables}

As noted in the Introduction, resistance may manifest either at the level of the investor or across the board. Our primary dependent variable is a dichotomous measure equal to one if, in a given investing coalition-country-year, there occurs either the former type of event, which we 
refer to as a dispute and may be initiated by the investor in response to adverse government action or in action, or the latter, which we refer to as wholesale policy change.

Our coding of events is conservative because our measures capture only those policy changes and disputes severe enough to warrant press coverage. This biases our coefficient estimator downward, reducing the probability of finding a statistically significant relationship. In our sensitivity analyses, we also examine the robustness of our results to the disaggregation of the dependent variable into its constituent components.

\subsection{Independent Variables}

Degree of coercion. We measure the degree to which a reform has been "coerced" by the World Bank, IMF or other multilateral lenders using results from Henisz, Zelner and Guillén (2004), who model the effect of multilateral lending on a country's adoption of market-oriented reforms in electricity generation, taking into account the country's propensity to borrow from multilateral institutions, the adoption decisions of other countries (weighted by their trade with the focal country), and a series of relevant domestic political and economic factors. When all other variables are held constant at their mean level in 1997, a one standard deviation increase in multilateral exposure (net borrowing from multilateral lenders as a percentage of GDP) is predicted to generate an 81 percent increase in the probability of a change in market-oriented reforms. In the current analysis, we measure the extent to which the emergent institutions governing private investment in a country's electricity sector are coerced by multilateral lenders as the difference between the probability that a country would adopt a reform in the year in which its reform program began as predicted by (1) a model that omits the role of multilateral lenders and (2) a model that includes the role of multilateral lenders. Table 1 lists the countries 
and the extent to which they were more or less likely to adopt reforms in the fully specified model of Henisz, Zelner and Guillén (2004) that includes the role of multilateral lenders.

Crises. We combine the coding schemes of (Frankel and Rose, 1996; Detragiache and Spillimbergo, 2001; Hamann and Prati, 2002; Beers, 2003; Kaminsky, 2003), who collectively identify 10 different types of crisis including currency crises, banking crises, stabilization episodes and various forms of default, to construct a dichotomous measure of the existence of a financial or macroeconomic crisis in a given country in a given year. Table 2 provides a listing of the country-years in which a crisis has occurred according to the most inclusive definition.

Vintage. We create a variable measuring reform vintage that is initially zero for each country and increases by one for each additional year following the initiation of electricity sector reforms. The initial year of reform is that in which (1) the regulator becomes independent from the ministry, or (2) the regulator becomes independent from the state-owned electricity generating company, or (3) entry by new private generators for resale to final customers is permitted. Table 3 provides a list of the initial reform year for the countries in our sample.

Checks and balances in established political institutions. Our measure of checks and balances is the "Political Constraints Index", (POLCON) developed by Henisz (2000). ${ }^{14}$ The first step in constructing this measure is the identification of the number of independent branches of government (executive, lower and upper legislative chambers, judiciary and sub-federal institutions) with veto power over policy change in each country. Countries lacking any formal veto points are assigned a score of " 0. ." For all other countries, the majority preference of each of these branches and the status quo policy are then assumed to be independently and identically

\footnotetext{
${ }^{14}$ Data and codebook are available from http://www-management.wharton.upenn.edu/henisz/POLCON/ ContactInfo.html
} 
drawn from a uniform, one-dimensional policy space $[0,1]$. This assumption allows for the derivation of a quantitative measure of institutional constraints using a simple spatial model of political interaction.

This initial measure is then modified to take into account the extent of alignment across branches of government using data on the party composition of the executive and legislative branches. Alignment across branches increases the feasibility of policy change, thereby reducing the level of political constraints. The measure is then further modified to capture the extent of preference heterogeneity within each legislative branch. Greater within-branch heterogeneity increases (decreases) the costs of overturning policy for aligned (opposed) branches. Possible scores for the final measure of political constraints range from zero (least constrained) to one (most constrained).

Countries with the greatest level of veto points in the formal policymaking apparatus are those federal states with strong independent judiciaries and either presidential systems or proportional representation electoral rules that tend to yield coalition governments, such as the United States, Germany and Switzerland. Political constraints decrease as the number of veto players declines or as their preferences become more homogeneous, as is the case in moving to a mixed Parliamentary-Presidential system, typified by France or Brazil; to heavily fractionalized Parliamentary systems like those of Belgium, Israel and the Netherlands; to Westminster Parliamentary systems with winner-take-all districts, such as the United Kingdom's. Nondemocratic countries and those with transitional political regimes have the lowest levels of political constraints because the formal institutional structures in these states provide tremendous discretion to policymakers. Table 4 provides the average observed value of political constraints for each country in our sample. 
Experience of Investing Coalition. We construct an investor experience measure by (1) calculating for each individual investor ${ }^{15}$ the cumulative number of years that it has been involved in each of its projects for each period, (2) summing each investor's cumulative experience across all projects in a given country for each period, (3) multiplying the resulting figure for each investor by its equity stake in a given project, and (4) summing the resulting figure for all investors in a given investor coalition. Our investor experience variable is thus an equity-weighted measure of the country-specific experience of each investing coalition.

Other Independent Variables. We also include the per capita income of the country to measure a country's level of economic development. We expect that, independent of our arguments about legitimacy, the material interests of consumers and private investors in poorer countries are more divergent, leading to a greater incidence of policy changes and disputes. We also include a variable measuring the size of a generating facility (in megawatts) to capture its visibility or political salience. Both of these variables are logarithmically transformed to take into account their extreme skewness. Table 5 provides descriptive statistics and a correlation matrix.

\subsection{Modeling Procedure}

We estimate the effects of independent variables on the occurrence of a dispute or wholesale policy change using an event history analysis, a technique that assesses the influence of a set of covariates on the incidence of an event using a longitudinal record of events in a sample from a population. In our model, each investor coalition is at risk of an adverse event in each country in which it has a stake in a power plant in each time period or until an adverse event occurs. This technique models the rate of a transition from an origin state to a destination state

\footnotetext{
${ }^{15}$ Investor names were carefully screened to eliminate multiple names for the same firm as well as to take into account mergers, acquisitions and divestitures. In the latter cases, organizational memory, ties and influence were presumed to survive a change in ownership.
} 
(adverse event) as a function of the covariates. Our primary specification employs a Weibull model:

$$
h(t)=\rho \lambda t^{\rho-1}, \lambda=e^{X_{j i} \beta}
$$

where $h(t)$ is the hazard function for a reform to transition from non-adoption to adoption at time $t$, with the observed covariate row vectors $X_{j t}$ and parameters to be estimated $\rho$ and $\beta$ (Blossfeld and Rohwer, 1995). To take into account the existence of multiple observations (investor coalitions) per country, we cluster the standard errors by country. ${ }^{16}$

To address problems of multicollinearity and facilitate the interpretation of the results, we mean-centered the constituent variables in our two-way interaction terms. Preliminary data analysis uncovered substantial nonlinearities in multiple independent variables across the subsamples of crisis and non-crisis years.

Because our model already includes multiple two-way interaction terms (multilateral influence X crisis, multilateral influence X political constraints, and multilateral influence $X$ clock), we chose to present the results for the full sample as well as results for the crisis- and crisis subsamples rather than grapple with the additional complexity of three-way interaction terms.

\section{Results}

\subsection{Foreign Coercion and Mediating Variables}

Table 6 displays our results in the full sample (column 1) and the subsamples of crisis (column 2) and non-crisis years (column 3). In all specifications, investors are less likely to

\footnotetext{
${ }^{16}$ Our results are also robust to clustering the standard errors by country-year as well as implementing a shared frailty model allowing for unobserved heterogeneity at the country level.
} 
encounter resistance in countries with higher levels of per capita income and for investments of smaller size.

In the full sample, we find no baseline support for a positive association between the extent to which the adoption of a reform program was influenced by multilateral lenders and subsequent resistance (Hypothesis 1). However, we do find a strong positive association between multilateral influence on reform adoption and the likelihood of resistance in crisis years (the coefficient estimate on the interaction between multilateral influence on reform adoption and crisis in column 1 and the coefficient estimate on multilateral influence on reform adoption in column 2 are both positive and significant). These results suggest that multilateral influence does reduce legitimacy, and thus increase the likelihood that investors will encounter resistance, during periods of economic distress, when actors in society are more likely to reevaluate emergent institutions (Hypothesis 2).

The economic significance of these results is noteworthy. When all other variables are held constant at their mean level, investors in countries for which the predicted influence of multilateral lending is one standard deviation above the mean (e.g., Ecuador and the Dominican Republic) and that encountered a financial or macroeconomic crisis exhibit a probability of resistance 23 times higher than that for countries in which multilateral lending has no predicted influence on reform adoption and there is no macroeconomic or financial crisis. Neither the occurrence of a crisis nor a high level of multilateral influence is sufficient to generate a predicted increase in resistance in the absence of the other variable.

The presence of a crisis also strongly affects the remaining negative moderating relationships (vintage and political constraints) as well as the negative effect of investor coalition experience. In crisis years, the vintage of market-oriented reforms more greatly mitigates the 
negative relationship between multilateral influence and resistance encountered by investors, suggesting that investors in countries with greater multilateral influence on the adoption of reforms are less likely to encounter resistance if they enter that country some time after the adoption of emergent regulative institutions (Hypothesis 3). Investors who entered a country in the year of the adoption of the emergent institutions had a predicted level of resistance 77 percent higher than the baseline hazard in crisis years whereas investors who waited for five years after the adoption of the emergent institutions experienced a 36 percent decrease in the predicted hazard of resistance. As for non-crisis years, we find a puzzling positive (albeit small in economic magnitude) relationship between the vintage of emergent institutions in non-crisis years and the probability of resistance faced by investors.

Turning to the effect of political constraints, we find that investors in countries with more developed checks and balances in their established political institutions have a far lower predicted level of resistance to reforms whose adoption was more strongly influenced by multilateral lending (Hypothesis 4), and that the magnitude of this effect is substantially stronger in crisis years than in non-crisis years. Investors that entered countries with political constraints one standard deviation below the mean level (e.g., Mali, Pakistan and Tunisia) had a predicted hazard of resistance over sixteen times the baseline level in crisis years (320 percent higher in non-crisis years), whereas investors that entered countries with political constraints one standard deviation above the mean level (e.g., Australia, Belgium and Germany) experienced a 94 percent decrease in the predicted hazard of resistance (68 percent in non-crisis years).

Finally, consistent with Hypothesis 5, we find that investor coalitions with more host country experience are less likely to encounter resistance and that this relationship is also much stronger in crisis than non-crisis years. Investing coalitions with one standard deviation below 
the mean level of experience had a predicted hazard of resistance 302 percent higher than the baseline in crisis years whereas investors with one standard deviation above the mean level enjoyed a 79 percent reduction in predicted hazards. Hazard rate multipliers for these and other combinations of the independent variables of theoretical interest are displayed in Table 7 . We also provide plots of the effects of varying individual independent variables of theoretical interest on the predicted annual hazard rate while holding all other variables constant at their mean levels for countries experiencing a crisis in Figures 1 - 4.

As a check on our results, we examine the investment projects with the highest predicted probability of resistance in the 1999 - 2001 period that had not yet experienced unilateral policy changes or bilateral disputes by 2001, the final year of our sample period. Table 8 displays the ten such cases with the highest predicted probability of resistance, along with a brief synopsis of their experiences in $2002-04$. The baseline probability of resistance in our model is 12.4 percent, and of the ten cases, five exhibited a dispute or wholesale policy change, while another three experienced some informal resistance or delay.

\subsection{Sensitivity Tests}

In order to demonstrate the robustness of our results, we conduct several sensitivity tests. First, we disaggregate our dependent variable into its constituent components (unilateral government policy changes adverse to investor interests and bilateral disputes between the investor and the government). Table 9 depicts these results, which are similar but not identical for the two types of events. For example, in the absence of a crisis, foreign coercion has larger effect on the probability of a dispute than it does on that of a unilateral policy changes, whereas a crisis has a greater aggravating impact on policy changes that it does on disputes. Vintage plays a greater moderating role on policy changes and the experience of the investing coalition is only 
weakly effective in reducing the probability of a dispute. An increase in per capita income level reduce the probability of a dispute but not that of a policy change, and political constraints increase the probability of disputes in countries that initiate a reform program in the absence of foreign coercion. Despite these differences across the two types of events, we still see a positive impact of foreign coercion in the presence of a crisis (Hypothesis 2), a moderating role for political constraints (Hypothesis 4) and a benefit of experience (Hypothesis 5) in both sets of regression results.

Next, we rotate in additional independent variables that might plausibly be related to resistance, but whose inclusion in our primary specification significantly reduces the sample size. These include the incidence of change in the political regime of a country, the incidence of change in the political leadership of a country, the extent of a country's democratization, the government's share of national output in a country, the country's openness (measured using either the dichotomous Sachs \& Warner (1995) or Wacziarg \& Welch (2003) indices), the performance of the electricity sector (measured either in terms of output generated or output generated and delivered to final customers) and the change in that performance since the adoption of the emergent institutions. None of these variables is statistically significant, nor does its inclusion alter the support for our hypotheses (results available from the authors upon request).

Finally, we test the sensitivity of your results to our choice of the Weibull functional form by estimating the model using exponential, Gompertz, and Cox proportional hazard models. Once again, none of these changes has any substantive effect on our core results (results available from the authors upon request). 


\section{Discussion}

\subsection{Foreign Coercion and the Sustainability of Emergent Institutions}

The empirical phenomenon that we investigate is adoption of emergent regulative structures to govern electricity generation in response to the coercive influence of multilateral lenders. We argue and find evidence that such coercion is likely to generate domestic resistance, particularly in countries with volatile economic environments and established political institutions lacking checks and balances.

Our results also speak to a larger class of phenomena. As the constraint of geography weakens due to globalization and technological change, political and economic organizations face increasing pressures from external political and economic actors. Multilateral organizations pressure countries to adopt reforms, just as competition from afar or demands from a distant headquarters pressures local companies to adopt reforms. The impetus for institutional or organizational change is thus increasingly distant in terms of identity. Under such conditions, coercive influences seeking institutional change, long assumed to possess both power and legitimacy, are increasingly likely to lack the latter characteristic.

Will the sanction of a given policy instrument or institutional characteristic by the European Union lead to adoption by member states? What effect will the adoption of a given organizational practice by an American firm have on its Japanese or Chinese competitors? What about the impact of a given organizational practice's adoption by an American multinational's headquarters on the company's Bolivian subsidiary? Our results suggest that in instances in which a powerful external actor promotes institutional or organizational change by distant actors, resistance to the emergent institution will be a function of (1) local environmental conditions that help opponents focus attention on the illegitimacy of the emergent institution (e.g., poor economic results in the focal organization that facilitate the scapegoating of the external actor); 
(2) local decision-making structures that restrict the discretion of local decision-makers (e.g., lower functional independence of a local subsidiary from its regional or corporate headquarters); (3) vintage, which facilitates institutionalization of the new practice; and (4) characteristics of the interest parties that enhance their ability to mobilize or diffuse resistance (e.g., the national identity of a local executive or the sophistication of a local lobbyist).

\subsection{Multilateral Lending and the Backlash Against Globalization}

This research also contributes to the scholarly and policy literatures on multilateral conditionality, particularly as these literatures relate to the backlash against globalization observed in a growing number of developing countries. Prior literature within political sociology and comparative political science has examined the resistance to multilateral reforms. The key findings from this literature emphasize the role of urbanization and other local environmental factors in facilitating the organization of resistance (Walton and Ragin, 1990), as well as the role of political structures that restrict discretionary policy change (MacIntyre, 2001). These studies do not exploit variation in the extent of foreign coercion across countries, the subsequent evolution of environmental conditions or the characteristics of key actors within these countries. In contrast, the policy literature on means to enhance the domestic ownership of multilateral reforms emphasizes mechanisms that reduce the illegitimacy of multilateral influence on a reform, but pays less attention to the extent to which environmental, political and organizational characteristics of the lending countries interact with these mechanisms. Our results suggest a need to combine the two perspectives.

Especially in countries prone to economic or financial crises and lacking checks and balances in established political institutions, we find that emergent institutions whose adoption is heavily influenced by multilateral actors are almost certain to face resistance. Efforts to enhance 
local ownership in these contexts, most likely by increasing access by the poor, are necessary. While some internal policy studies emphasize the need for a shift in this direction, other authors continue to cling to the notion that redistributive deviations from economic efficiency are unnecessary or counterproductive. Our results suggest that that such efforts to enhance ownership, although potentially costly in the short term, may be necessary for the emergent institutions to stand the test of time. In the absence of such efforts, the political resistance that the current solutions are generating, despite higher economic efficiency, could lead to their dismantling (e.g., the recent renationalization of parts of the Argentine electricity system). Resistance could also lead national governments to rally against foreign coercion in general, thus undermining multilateral institutions' ability to secure future institutional change. While multilateral actors may have as their goal the implementation of economically efficient policies, the enacting and maintenance of these policies is a political act that requires careful attention not just to the political incentives of fully rational economic actors, but to the complex interplay of cognitive frames, interest group lobbying, formal political structures at the national level, and international relations.

\subsection{Limitations and Future Research}

Although we believe that our analysis makes an important contribution, we also acknowledge several shortcomings. First, it does not identify the mechanisms that opposed interest groups use to rally sympathetic but inactive peers to their cause. Additionally, while our results are consistent with the hypotheses that financial or macroeconomic crises enhance the efficacy of such groups, the foreign identity of multilateral actors further facilitates these efforts, checks and balances in established political institutions moderate these pressures, and investor coalitions with substantial host country experience are able to insulate themselves from adverse 
policy outcomes or potential disputes, future research using comparative cases (e.g., Elsbach (1994)) or content analysis of media reports should seek to more closely identify the underlying processes at work. Only such micro-level studies can provide concrete operational guidance to political and economic actors seeking to enhance the survival of emergent institutions, or to their opponents seeking to resist the institutionalization of such changes.

Our results also do not speak directly to the underlying desirability of the adoption and institutionalization of emergent institutions supported by multilateral lenders. Particularly in the context of the normative debate surrounding multilateral conditionality, this is an important issue. Existing research already demonstrates the efficacy of the deregulation, privatization and liberalization of infrastructure services in general (Ros, 1999; Boylaud and Nicoletti, 2000; Fink, Mattoo, and Rathindran, 2002; Wallsten, 2002; Jamasb, et al., 2004). However, it is possible that this empirical result is an artifact of a selection problem. Early adopters may possess the requisite institutional structures that support market-oriented reforms, undertake such reforms independent of multilateral influence and subsequently enjoy welfare gains, while later adopters may lack supporting institutional structures, undertake reforms in response to multilateral influence and subsequently suffer welfare losses. The results obtained by analyzing efficiency among early adopters would thus lead to incorrect inferences about the potential gains to remaining countries due to the self-selection of countries with supporting institutional structures into the adopting sample. Further, even after data are amassed on countries that adopt reforms in response to multilateral influence, results obtained by pooling these two groups without distinguishing between them would reflect "mean" results, possibly suggesting the efficacy of market-oriented reforms and supporting further multilateral coercion if the former group dominates the pooled sample. Future research should thus compare sector-specific economic outcomes (e.g., increases 
in electricity output, decreases in line losses or reductions in concentration of ownership) in countries that adopted deregulation, privatization and liberalization indigenously versus as a component of a multilateral lending program. 


\section{REFERENCES}

Alesina, Alberto

1989 "Politcs and Business Cycles in Industrial Democracies." Economic Policy, 4: 55-98.

Alesina, Alberto and Allan Drazen

1991 "Why Are Stabilizations Delayed?" American Economic Review, 81: 1170-1188.

Amenta, Edwin, Bruce G. Carruthers, and Yvonne Zylan

1992 "A Hero for the Aged? The Townsend Movement, the Political Mediation Model and U.S.

Old-Age Policy, 1934-1950." American Journal of Sociology, 98: 308-339.

Andrews, Kenneth T.

1997 "The Impacts of Social Movements on the Political Process: The Civil Rights Movement and Black Electoral Politics in Mississippi." American Sociological Review, 62: 800-819.

2001 "Social Movements and Policy Implementation: The Mississippi Civil Rights Movement and the War on Poverty, 1965 to 1971." American Sociological Review, 66: 71-95.

Astley, W. Graham

1985 "The Two Ecologies: Population and Community Perspectives on Organizational

Evolution." Administrative Science Quarterly, 30: 224-241.

Babb, Sarah L.

2003 "The Imf in Sociological Perspective: A Tale of Organizational Slippage." Studies in Comparative International Development, 38: 3-27.

Barkan, Steven E.

1984 "Legal Control of the Southern Civil Rights Movement." American Sociological Review, 49: 552-565.

Baron, James N., P. Deveraux Jennings, and Frank R. Dobbin

1988 "Mission Control? The Development of Personnel Systems in U.S. Industry." American

Sociological Review, 53: 497-514.

Baum, Joel A. C. and Paul Ingram

1998 "Survival-Enhancing Learning in the Manhattan Hotel Industry." Management Science, 44: 996-1016.

Baum, Joel A. C., Stan X. Li, and John M. Usher

2000 "Making the Next Move: How Experiential and Vicarious Learning Shape the Locations of

Chains' Acquisitions." Administrative Science Quarterly, 45: 766-801.

Baum, Joel A. C. and Christine Oliver

1992 "Institutional Embeddedness and the Dynamics of Organizational Populations." American

Sociological Review, 57: 540-559.

Baumgartner, Frank R.

2002 "Social Movements, the Rise of New Issues and the Public Agenda." In D. S. Meyer, V.

Jenness, and H. Ingram (eds.), Social Movements, Public Policy and Democracy.

Baumgartner, Frank R. and Christine Mahoney

2002 "Gaining Government Allies: Groups, Officials and Alliance Behavior."

Becker, Gary S.

1983 "A Theory of Competition among Pressure Groups for Political Influence." Quarterly Journal of Economics, 98: 371-400.

Beers, David T.

2003 "Sovereign Defaults: Heading Lower into 2004." New York, NY: Standard \& Poor's.

Bendix, Richard 
1978 Kings or People: Power and the Mandate to Rule. Berkeley, CA: University of California Press.

Benford, Robert D. and David A. Snow

2000 "Framing Processes and Social Movements: An Overview and Assessment." Annual

Review of Sociology, 26: 611-639.

Benson, Kenneth J.

1975 "The Interorganizational Network as a Political Economy." Administrative Science Quarterly, 20: 229-249.

Berger, Peter L. and Thomas Luckman

1967 The Social Construction of Reality. New York: Doubleday.

Berkowitz, Edward and Kim McQuaid

1978 "Businessman and Bureaucrat: The Evolution of the American Social Welfare System, 1900-1940." Journal of Economic History, 38: 120-142.

Bienen, Henry and Nicolas Van de Walle

1991 Of Time and Power: Leadership Duration in the Modern World. Stanford, CA: Stanford University Press.

Blossfeld, Hans-Peter and Gotz Rohwer

1995 Techniques of Event History Modeling : New Approaches to Causal Analysis. Mahwah, NJ: Erlbaum.

Boddewyn, Jean J. and Thomas L. Brewer

1994 "International Business Political Behavior: New Theoretical Directions." Academy of Management Review, 19: 119-143.

Boorman, Jack

2001 "Strengthening Country Ownership of Fund-Supported Programs." International Monetary Fund Report.

Boughton, James M.

2003 "Who's in Charge? Ownership and Conditionality in Imf-Supported Programs." IMF Working Paper, 03.

Boylaud, Olivier and Giuseppe Nicoletti

2000 "Regulation, Market Structure and Performance in the Telecommunications." OECD Economics Working Paper No. 237, 2000.

Brune, Nancy, Geoffrey Garrett, and Bruce Kogut

2004 "The International Monetary Fund and the Global Spread of Privatization." IMF Staff Papers, 51.

Buira, Ariel

2003 "An Analysis of Imf Conditionality." XVI Technical Group Meeting of the Intergovernmental Group of 24. Port of Spain, Trinidad and Tobago.

Busch, Andreas

2004 "National Filters: Europeanisation, Institutions and Discourse in the Case of Banking Regulation." West European Politics, 27: 310-333.

Campbell, John L.

1996 "An Institutional Analysis of Fiscal Reform in Postcommunist Europe." Theory and Society, 25: 45-84.

Cederman, Lars-Erik

2001 "Nationalism and Bounded Integration: What It Would Take to Construct a European Demos." European Journal of International Relations, 7: 139-174. 
Cole, Robert

1985 "The Macropolitics of Organizational Change: A Comparative Analysis of the Spread of Small Group Activities." Administrative Science Quarterly, 30: 560-585.

Cox, Gary W. and Matthew D. McCubbins

1993 Legislative Leviathan: Party Government in the House. Berkeley, CA: University of California Press.

Dacin, M. Tina

1997 "Isomorphism in Context: The Power and Prescription of Institutional Norms." Academy of Management Journal, 40: 46-81.

Denzau, Arthur T. and Michael C. Munger

1986 "Legislators and Interest Groups: How Unorganized Interests Get Represented." American Political Science Review, 80: 89-107.

Detragiache, Enrica and Antonio Spillimbergo

2001 "Crises and Liquidity: Evidence and Interpretation." International Monetary Fund Working Paper, 01.

DiMaggio, Paul J. and Walter W. Powell

1983 "The Iron Cage Revisited: Institutional Isomorphism and Collective Rationality in Organizational Fields." American Sociological Review, 48: 147-160.

Dixit, Avinash

1996 The Making of Economic Policy: A Transaction Cost Politics Perspective. Cambridge: MIT Press.

Dobbin, Frank

1993 "The Social Construction of the Great Depression: Industrial Policy During the 1930s in the United States, Britain and France." Theory and Society, 22: 1-56.

Dobbin, Frank R.

1994 Forging Industrial Policy: The United States, Britain and France in the Railway Age. Cambridge, UK: Cambridge University Press.

Dobbin, Frank, John R. Sutton, John W. Meyer, and Richard Scott

1993 "Equal Opportunity Law and the Construction of Internal Labor Markets." American Journal of Sociology, 99: 396-427.

Drazen, A. and V. Grilli

1993 "The Benefits of Crises for Economic Reform." American Economic Review, 83: 598-607.

Drazen, Allan and Peter Isard

2004 "Can Public Discussion Enhance Program 'Ownership'?" Festchrift in Honor of Guillermo A. Calvo.

Edelman, Lauren B.

1990 "Legal Environments and Organizational Governance: The Expansion of Due Process in the American Workplace." American Sociological Review, 95: 1401-1440.

Elsbach, Kimberly D.

1994 "Managing Organizational Legitimacy in the California Cattle Industry: The Construction and Effectiveness of Verbal Accounts." Administrative Science Quarterly, 39: 57-88.

Elsbach, Kimberly D. and Roderick M. Kramer

1996 "Members' Responses to Organizational Identity Threats: Encountering and Countering the Business Week Rankings." Administrative Science Quarterly, 41: 442-476.

Feldstein, Martin

1998 "Refocusing the Imf." Foreign Affairs, 77: 20-33. 
Fernandez, Raquel and Dani Rodrik

1991 "Resistance to Reform: Status Quo Bias in the Presence of Individual-Specific

Uncertainty." American Economic Review, 81: 1146-1155.

Fink, Carsten, Aaditya Mattoo, and Randeep Rathindran

2002 "An Assessment of Telecommunications Reform in Developing Countries." World Bank

Policy Research Paper, 2909.

Finnemore, Martha

1993 "International Organizations as Teachers of Norms: The United Nations Education,

Scientific and Cultural Organization and Science Policy." International Organization, 47: 565-597.

Fligstein, Neal

1990 The Transformation of Corporate Control. Cambridge, MA: Harvard University Press.

Fligstein, Neal and Alec Stone Sweet

2002 "Constructing Polities and Markets: An Institutionalist Account of European Integration."

Annual Journal of Sociology, 107: 1206-1243.

Fourcade-Gourinchas, Marion and Sarah L. Babb

2002 "The Rebirth of the Liberal Creed: Paths to Neoliberalism in Four Countries." American Journal of Sociology, 108: 533-579.

Fox-Wolfgramm, Susan J., Kimberly B. Boal, and James G. Hunt

1998 "Organizational Adaptation to Institutional Change: A Comparative Study of First-Order Change in Prospector and Defender Banks." Administrative Science Quarterly, 43: 87126.

Frank, D., A. Hironaka, and E. Schofer

2000a "Environmental Protection as a Global Institution." American Sociological Review, 65:

$122-127$.

2000b "The Nation State and the Natural Environment, 1900-1995." American Sociological

Review, 65: 96-116.

Frankel, Jeffrey A. and Andrew K. Rose

1996 "Currency Crises in Emerging Markets: Empirical Indicators." Journal of International Economics, 41: 351-367.

Franzese Jr., Robert J.

1999 "Partially Independent Central Banks, Politically Responsive Governments and Inflation." American Political Science Review, 43: 681-706.

Gamson, WA, B. Fireman, and S. Rytina

1982 Encounters with Unjust Authority. Homewood, IL: Dorsey.

Garrett, Geoffrey

2000 "Globalization and Government Spending around the World." Mimeo.

Gely, Rafael and Pablo T. Spiller

1990 "A Rational Choice Theory of the Supreme Court Statutory Decisions with Applications to the State Farm and Grove City Cases." Journal of Law, Economics, and Organization, 6: 263-301.

Gilligan, Thomas, W. and Keith Krehbiel

1980 "Collective Choice without Procedural Commitment." In P. Ordeshook (ed.), Models of Strategic Choice in Politics: 295-314. Ann Arbor: University of Michigan Press.

Gilligan, Thomas W., William J. Marshall, and Barry R. Weingast 
1989 "Regulation and the Theory of Legislative Choice: The Interstate Commerce Act of 1887." Journal of Law and Economics, 32: 35-61.

Glick, Reuven and Andrew K. Rose

1998 "Contagion and Trade: Why Are Currency Crises

Regional?" National Bureau of Econoimic Research Working Paper, 6806.

Greenwood, Royston and C. R. Hinings

1996 "Understanding Radical Organizational Change: Bringing Together the Old and the New Institutionalism." The Academy of Management Review, 21: 1022-1054.

Griffin, Larry J., Wallace. Michael E., and Beth A. Rubin

1986 "Capitalist Resistance to the Organization of Labor before the New Deal: Why? How? Success?" American Sociological Review, 51: 147-167.

Guillén, Mauro

2001a "Is Globalization Civilizing, Destructive or Feeble? A Critique of Six Key Debates in the Social-Science Literature (Or: Everything You Always Wanted to Know About Globalization but Never Dared to Ask)." Annual Review of Sociology, 27: 235-260.

$2001 b$ The Limits of Convergence: Globalization and Organizational Change in Argentina, South Korea, and Spain. Princeton, NJ: Princeton University Press.

Guler, Isin, Mauro Guillén, and Muir Macpherson

2002 "Global Competition, Institutions, and Organizational Change: The International Diffusion of the Iso 9000 Quality Standards." Administrative Science Quarterly, 47: 207-232.

Hallerberg, Mark and Scott Basinger

1998 "Internationalization and Changes in Tax Policy in Oecd Countries: The Importance of Domestic Veto Players." Comparative Political Studies, 31: 321-352.

Hamann, A. Javier and Alessandro Prati

2002 "Why Do Many Disinflations Fail? The Importance of Luck, Timing, and Political Institutions." International Monetary Fund Working Paper, 02.

Hansen, Lene and Michael Williams

1999 "The Myths of Europe: Legitimacy, Community and the 'Crisis' of the Eu." Journal of Common Market Studies, 37: 233-249.

Haveman, Heather A.

1993a "Follow the Leader: Mimetic Isomorphism and Entry into New Markets." Administrative Science Quarterly, 38: 564-592.

$1993 b$ "Organizational Size and Change: Diversification in the Savings and Loan Industry after Deregulation." Administrative Science Quarterly, 38: 20-50.

Heaver, Richard and Arturo Israel

1986 "Country Commitment to Development Projects." World Bank Discussion Paper, 4. Helleiner, Gerry

2000 "Towards Balance in Aid Relationships: External Conditionality, Local Ownership and Development." Reality of Aid International Advisory Meeting. Costa Rica.

Henisz, Witold J. and Andrew Delios

2001 "Uncertainty, Imitation, and Plant Location: Japanese Multinational Corporations, 19901996." Administrative Science Quarterly, 46: 443-475.

Henisz, Witold J. and Bennet A. Zelner

2005 "Legitimacy, Interest Group Pressures and Change in Emergent Institutions: The Case of Foreign Investors and Host Country Governments." Academy of Management Review, 30: Forthcoming. 
Henisz, Witold J., Bennet A. Zelner, and Mauro F. Guillén

2004 "Coercion, Emulation and Credibility in Policy Reform." William Davidson Institute Working Paper, 713.

Henisz, Witold Jerzy

2000 "The Institutional Environment for Economic Growth." Economics and Politics, 12: 1-31.

2004 "Political Institutions and Policy Volatility." Economics and Politics, 16: 1-27.

Hilgartner, Stephen and Charles L. Bosk

1988 "The Rise and Fall of Social Problems: A Public Arenas Model." American Journal of Sociology, 94: 53-78.

Hoffman, Andrew J.

1999 "Institutional Evolution and Change: Environmentalism and the U.S. Chemical Industry." Academy of Management Journal, 42: 353-371.

Holm, Peter

1995 "The Dynamics of Institutionalization: Transformation Processes in Norwegian Fisheries." Administrative Science Quarterly, 40: 398-422.

Horeth, Marcus

1999 "No Way out for the Beast? The Unsolved Legitimacy Problem of European Governance." HJournal of European Public Policy, 6: 249-268.

Ingram, Paul

1998 "Changing the Rules: Interests, Organizations and Institutional Change in the U.S.

Hospitality Industry." In M. C. Brinton and V. Nee (eds.), New Institutionalism in

Sociology: 258-276. New York: The Russel Sage Foundation.

Jamasb, Tooraj, Rafaella Mota, David Newbery, and Michael G. Pollitt

2004 "Electricity Sector Reform in Developing Countries: A Survey of Empirical Evidence on

Determinants and Performance." Mimeo.

James, Harold

1996 International Monetary Cooperation since Bretton Woods. Washington D.C.: International Monetary Fund.

Jasper, James M. and Jane Poulsen

1993 "Fighting Back: Vulnerabilities, Blunders and Countermobilization by the Targets in Three Animan Rights Campaigns." Sociological Forum, 8: 639-657.

Jenkins, J. Craig and Charles Perrow

1977 "Insurgency of the Powerless: Farm Worker Movements (1946-1972)." American Sociological Review, 42: 249-268.

Jones, Bryan D., Frank R. Baumgartner, and James L. True

1998 "Policy Punctuations: U.S. Budgetary Authority, 1947-1995." Journal of Politics, 60: 1-33. Jones, Philip

1978 "The Appeal of the Political Entrepreneur." British Journal of Political Science, 8: 498-504. Kaminsky, Graciela L.

2003 "Varities of Currency Crises." National Bureau for Economic Research Working Paper, 10193.

Kerbo, Harold R. and Richars A Shaffer

1992 "Lower Class Insurgency and the Political Process: The Response of the U.S. Unemployed, 1890-1940." Social Problems, 39: 139-154.

Khan, Mohsin S. and Sunil Sharma 
2003 "Imf Conditionality and Country Ownership of Adjustment Programs." World Bank Research Observer, 18: 227-248.

Kikeri, Sunita and John Nellis

2004 "An Asessment of Privatization." World Bank Research Observer, 19: 87-118.

Kingdon, John W.

1984 Agendas, Alternatives, and Public Policies. Boston: Little, Brown.

Kogut, Bruce and J. Muir Macpherson

2004a "The Decision to Privatize as an Economic Policy Idea: Epistemic Communities and Diffusion." Mimeo.

2004b "The Decision to Privatize as an Economic Policy Idea: Epistemic Communities, Palace Wars and Diffusion." mimeo.

Kogut, Bruce and Andrew Spicer

2002 "Capital Market Development and Mass Privatization Are Logical Contradictions: Lessons from the Czech Republic and Russia." Industrial and Corporate Change, 11: 1-37.

2004 "The Sacred and Profane Revised: Academic Entrepreneurs and the Positive Feedback of Participation in World Events on Their Careers and Ideas." Mimeo.

Krieger, Leonard

1963 "The Idea of the Welfare State in Europe and the United States." Journal of the History of Ideas, 24: 553-568.

Laffan, Brigid

2001 "The European Union Polity: A Union of Regulative, Normative and Cognitive Pillars." Journal of European Public Policy, 8: 709-727.

Laffont, Jean-Jacques

1999 "Political Economy, Information and Incentives." European Economic Review, 43: 649669.

Landes, David S.

1998 The Wealth and Poverty of Nations. New York: W.W. Norton \& Company.

Lau, Richard R., Richard A. Smith, and Susan T. Fiske

1991 "Political Beliefs, Policy Interpretations and Political Persuasion." Journal of Politics, 53: 644-675.

Levitt, Barbara and Clifford Nass

1989 "The Lid on the Garbage Can: Institutional Constraints on Decision Making in the Technical Core of College-Text Publishers." Administrative Science Quarterly, 34: 190207.

Levy, Brian and Pablo T. Spiller

1994 "The Institutional Foundations of Regulatory Commitment: A Comparative Analysis of Telecommunications Regulation." Journal of Law, Economics and Organization, 10: 201246.

Lipset, Seymour Martin

1959 "Some Social Requisites of Democracy: Economic Development and Political Legitimacy." American Political Science Review, 53: 69-105.

Lipsky, Michael

1968 "Protest as a Political Resource." American Politcial Science Review, 62: 1144-1158.

Lowi, Theodore

1969 The End of Liberalism; Ideology, Policy, and the Crisis of Public Authority. New York:

Norton. 
Lyles, Marjorie A. and H. Kevin Steensma

1996 "Competition for Large-Scale Infrastructure Projects in the Emerging Asian Markets:

Factors of Success." Columbia Journal of World Business: 64-75.

MacIntyre, Andrew

2001 "Institutions and Investors: The Politics of the Financial Crisis in Southeast Asia." International Organization, 55: 81-122.

Mansuri, Ghazala and Viyajendra Rao

2004 "Community-Based and -Driven Development: A Critical Review." World Bank Research Observer, 19: 1-39.

March, James G. and Herbert Simon

1958 "Organizations." New York: John Wiley.

McAdam, Doug, John D. McCarthy, and Mayer N. Zald

1996 "Introduction: Opportunities, Mobilizing Structures and Framing Processes -- toward a Synthetic, Comparative Perspective on Social Movements." In D. McAdam, J. D. McCarthy, and M. N. Zald (eds.), Comparative Perspectives on Social Movements: Political Opportunities, Mobilizing Structures and Cultural Framings. Cambridge, UK: Cambridge University Press.

McFarland, Andrew S.

1991 "Interest Groups and Political Time: Cycles in America." British Journal of Political Science, 21: 257-284.

McNollGast

1987 "Administrative Procedures as Instruments of Political Control." Journal of Law, Economics and Organization, 3: 243-277.

Meyer, John and Brian Rowan

1977 "Institutionalized Organizations: Formal Structures as Myth and Ceremony." American Journal of Sociology, 83: 340-363.

Meyer, John W., John Boli, George M. Thomas, and Francisco O. Ramirez

1997 "World Society and the Nation State." American Journal of Sociology, 103: 144-181.

Mlcoch, Lubomir

1998 "Czech Priatisation: A Criticism of Misunderstood Liberalism." Journal of Business Ethics, 17: 951-959.

Moe, Terry and Michael Caldwell

1994 "The Institutional Foundations of Democratic Government: A Comparison of Presidential and Parliamentary Systems." Journal of Institutional and Theoretical Economics, 150: 171-195.

Morrow, Daniel

1999 "Assessing Borrower Ownership Using Reform Readiness Analysis." World Bank Poverty Reduction and Economic Management Note, 25.

Nelson, Joan

1990 "Economic Crisis and Policy Choice: The Politics of Adjustment in the Third World." Princeton: Princeton University Press.

Nordhaus, William

1975 "The Political Business Cycle." Review of Economic Studies, 42: 169-190.

North, Douglass C.

1990 Institutions, Institutional Change, and Economic Performance. New York: Cambridge University Press. 
North, Douglass C. and Barry R. Weingast

1989 "Constitutions and Commitment: The Evolution of Institutions Governing Public Choice in Seventeenth Century England." Journal of Economic History, 49: 803-832.

Oliver, Christine

1991 "Strategic Responses to Institutional Processes." Academy of Management Review, 16: 145-179.

Olson, Mancur

1965 The Logic of Collective Action: Public Goods and the Theory of Groups. Cambridge, MA: Harvard University Press.

Padgett, Stephen

2003 "Between Synthesis and Emulation: Eu Policy Transfer in the Power Sector." Journal of European Public Policy, 10: 227-245.

Patashnik, Eric

2003 "After the Public Interest Prevails: The Political Sustainability of Policy Reform." Governance, 16: 203-234.

Peltzman, Sam

1976 "Toward a More General Theory of Regulation." Journal of Law and Economics, 19: 211248.

Persson, Torsten and Guido Tabellini

1999 "Political Economics and Public Finance." National Bureau for Economic Research Working Paper, 7097.

Podolny, Joel M.

1993 "A Status-Based Model of Market Competition." American Journal of Sociology, 98: 829(844).

Quadagno, Jill

1987 "Theories of the Welfare State." Annual Review of Sociology, 13.

Razi, G. Hossein

1987 "The Nexus of Legitimacy and Performance: The Lessons of the Iranian Revolution." Comparative Politics, 19: 453-469.

Riain, Sean O.

2000 "States and Markets in an Era of Globalization." Annual Review of Sociology, 26: 187213.

Rogoff, Kenneth and Anne Sibert

1988 "Elections and Macroeconomic Policy Cycles." Review of Economic Studies, 55: 1-16.

Romanelli, Elaine and Michael L. Tushman

1994 "Organizational Transformation as Punctuated Equilibrium: An Empirical Test." Academy of Management Journal, 37: 1141-1166.

Ros, Agustin J.

1999 "Does Ownership or Competition Matter? The Effects of Telecommunications Reform on Network Expansion and Efficiency." Journal of Regulatory Economics, 15: 65-92.

Rowan, Brian

1982 "Organizational Structure and the Institutional Environment: The Case of Public Schools." Administrative Science Quarterly, 27: 259-279.

Ruef, Martin and W. Richard Scott

1998 "A Multidimensional Model of Organizational Legitimacy: Hospital Survival in Changing Institutional Environments." Administrative Science Quarterly, 43: 877-904. 
Sachs, Jeffrey D. and Andrew Warner

1995 "Economic Reform and the Process of Global Integration." Brookings Papers on Economic Activity: 1-118.

Schneider, Mark and Paul Teske

1992 "Toward a Theory of the Political Entrepreneur: Evidence from Local Government." American Political Science Review, 86: 737-747.

Schumaker, Paul D.

1975 "Policy Responsiveness to Protest-Group Demands." Journal Of Politics, 37: 488-521.

Scott, Richard W.

2001 Institutions and Organizations, Second ed. Thousand Oaks, CA: Sage Publications.

Sell, Susan K.

1995 "Intellectual Property Protection and Antitrust in the Developing World: Crisis, Coercion and Choice." International Organization, 49: 315-349.

Seo, Myeong-Gu and W.E. Douglas Creed

2002 "Institutional Contradictions, Praxis and Institutional Change: A Dialectical Perspective." Academy of Management Review, 27: 222-247.

Simons, Tal and Paul Ingram

2003 "Enemies of the State: The Interdependence of Institutional Forms and the Ecology of the Kibbutz, 1910-1997." Administrative Science Quarterly, 48: 592-621.

Singh, Jittendra V., David J. Tucker, and Robert J. House

1986 "Organizational Legitimacy and the Liability of Newness." Administrative Science Quarterly, 31: 171-193.

Sjöstrand, Sven-Erik

1995 "Toward a Theory of Institutional Change." In J. Groenewegen, C. Pitelis, and S.-E. Sjöstrand (eds.), Economic Institutions: Theory and Applications: 19-44. Aldershot, UK: Edward Elgar.

Skocpol, Theda and Edwin Amenta

1986 "States and Social Policies." Annual Review of Sociology, 12: 131-157.

Spicer, Andrew, Gerry McDermott, and Bruce Kogut

2000 "Entrepreneurship and Privatization in Central Europe: The Tenuous Balance between

Creation and Destruction." Academy of Management Review, 25: 630-649.

Spiller, Pablo T.

1993 "Institutions and Regulatory Commitment in Utilities' Privatization." Industrial and Corporate Change, 2: 387-450.

Staw, Barry M. and Lisa D. Epstein

2000 "What Bandwagons Bring: Effects of Popular Management Techniques on Corporate Performance, Reputation and Ceo Pay." Administrative Science Quarterly, 45: 535-556.

Steffek, Jens

2003 "The Legitimation of International Governance: A Discourse Approach." European Journal of International Relations, 9: 249-275.

Stigler, George

1975 The Citizen and the State: Essays on Regulation. Chicago: University of Chicago Press.

Stiglitz, Joseph

1999 "The Bank at the Milennium." Economic Journal, 109.

Strang, David 
1990 "From Dependency to Sovereignty: An Event History Analysis of Decolonization 18701987." American Sociological Review, 55: 846-860.

Strang, David and Ellen M. Bradburn

2001 "Theorizing Legitimacy or Legitimating Theory? Neoliberal Discourse and Hmo Policy, 1970-1989." In J. L. Campbell and O. K. Pedersen (eds.), The Rise of Neoliberalism and Institutional Analysis. Princeton, NJ: Princeton University Press.

Strang, David and Patricia Mei Yin Chang

1993 "The International Labor Organization and the Welfare State: Institutional Effects on Welfare Spending, 1960-80." International Organization, 47: 235-262.

Stryker, Robin

1994 "Rules, Resources and Legitimacy Processes: Some Implications for Social Conflict, Order and Change." American Journal of Sociology, 99: 847-910.

Suchman, M.C.

1995 "Managing Legitimacy: Strategic and Institutional Approaches." Academy of Management Review, 20: 571-610.

Sutton, John R. and Frank Dobbin

1996 "The Two Faces of Governance: Responses to Legal Uncertainty in U.S. Firms, 1955 to 1985."

Thatcher, Mark

2004 "Varities of Capitalism in an Internationalized World: Domestic Institutional Change in European Telecommunications." Comparative Politics, 37: 751-780.

Tiller, Emerson and Pablo T. Spiller

1999 "Strategic Instruments: Legal Strcuture and Political Games in Administrative Law." Journal of Law, Economics \& Organization, 15: 349-377.

Tolbert, Pamela S. and Lynne G. Zucker

1983 "Institutional Sources of Change in the Formal Structure of Organizations: The Diffusion of Civil Service Reform, 1880-1935." Administrative Science Quarterly, 28: 22-39.

Treisman, Daniel

2000 "Decentralization and Inflation: Commitment, Collective Action or Continuity." American Political Science Review, 94: 837-857.

Tsebelis, George

2003 Veto Players: How Political Institutions Work. Princeton, NJ: Princeton University Press and Russell Sage Foundation.

Tyler, Tom R.

1994 "Governing and Diversity: The Effect of Fair Decisionmaking Procedures on the Legitimacy of Government." Law \& Society Review, 28: 809-832.

Tyler, Tom R., KA Rasinski, and KM McGraw

1985 "The Influence of Perceived Injustice on the Endorsement of Political Leaders." Journal of Applied Social Psychology, 15: 700-725.

Wacziarg, Romain and Karen Horn Welch

2003 "Trade Liberalization and Growth: New Evidence." NBER Working Paper, 10152.

Wallsten, Scott

2002 "Does Sequencing Matter? Regulation and Privatization in Telecommunications Reform." Mimeo.

Walton, John and Charles Ragin 
1990 "Global and National Sources of Political Protest: Third World Responses to the Debt Crisis." American Sociological Review, 55: 876-890.

Weber, Max

1978 Economy and Society. Berkeley CA: University of California Press.

Weingast, Barry and William J. Marshall

1988 "The Industrial Organization of Congress; or, Why Legislators, Like Firms, Are Not

Organized as Markets." Journal of Political Economy, 96: 132-163.

Weingast, Barry and Mark Moran

1983 "Bureaucratic Discretion or Congressional Control? Regulatory Policymaking by the

Federal Trade Commission." Journal of Political Economy, 91: 765-800.

Weingast, Barry N.

1981 "Regulation, Reregulation and Deregulation: The Political Foundations of Agency Clientele Relationships." Law and Contemporary Problems, 44: 149-177.

Westney, Eleanor

1987 Imitation and Innovation: The Transfer of Western Organizational Patterns to Meiji Japan. Cambridge, MA: Harvard University Press.

Westphal, James D., Ranjay Gulati, and Stephen M. Shortell

1997 "Customization or Conformity: An Institutional and Network Perspective on the Content and Consequences of Tqm Adoption." Administrative Science Quarterly, 42: 366-394.

Williamson, John

1993 "The Political Economy of Policy Reform." Washington D.C.: Institute for International Economics.

Wilson, James Q.

1980 "The Politics of Regulation." In Wilson (ed.), The Politics of Regulation: 319-336. New York: Basic Books.

Witt, Michael and Arie Lewin

2004 "Dynamics of National Institutional Configurations: Implications for Country, Industry and Firm Adaptation." Mimeo.

Zucker, Lynne G.

1977 "The Role of Institutionalization in Cultural Persistence." American Sociological Review, 42: 726-743.

1987 "Institutional Theories of Organization." Annual Review of Sociology, 13: 443-464. 
Table 1: Extent of Multilateral Influence on Reform Adoption

\begin{tabular}{lc} 
Country & Extent of Multilateral Inducement (see text) \\
\cline { 2 - 2 } Nicaragua & 6.09 \\
Bolivia & 2.71 \\
Zimbabwe & 2.67 \\
Romania & 2.03 \\
Argentina & 1.94 \\
Chile & 1.16 \\
Ecuador & 1.00 \\
Dominican Republic & 0.82 \\
Sri Lanka & 0.25 \\
Jamaica & 0.08 \\
Tunisia & 0.03 \\
Thailand & -0.06 \\
Poland & -0.27 \\
Morocco & -0.32 \\
Malaysia & -0.33 \\
Bangladesh & -0.34 \\
Ghana & -0.39 \\
Kenya & -0.42 \\
Korea, Rep. & -0.49 \\
Pakistan & -0.65 \\
Turkey & -0.71 \\
Colombia & -0.73 \\
Philippines & -0.95 \\
Costa Rica & -1.28 \\
Hungary & -1.54 \\
Panama & -3.42 \\
India & -5.34 \\
Brazil & -5.74 \\
Mexico & -9.63
\end{tabular}

Note: Countries not included above have value of zero. 
Table 2: Country-Years of Financial or Macroeconomic Crisis

\begin{tabular}{llll} 
Country & \multicolumn{1}{l}{ Years } & Country & Years \\
ANTIGUA & $1996-01$ & JAPAN & $1991-01$ \\
ARGENTINA & $1992-93,1995,2001$ & KENYA & $1996-01$ \\
AUSTRALIA & 1992 & KOREA & $1997-01$ \\
BOLIVIA & $1994-01$ & MALAYSIA & $1997-01$ \\
BRAZIL & $1989-99$ & MEXICO & $1994-97$ \\
CHILE & 1990 & NICARAGUA & $1996-01$ \\
CHINA & $1990-99$ & NORWAY & $1990-93,1998-00$ \\
COLOMBIA & $1995,1997-99$ & PAKISTAN & $1998-99$ \\
CZECH REPUBLIC & $1995-01$ & PERU & $1995-97$ \\
DENMARK & $1990-93$ & PHILIPPINES & $1990-92,1997-01$ \\
DOMINICAN REPUBLIC & $1990-01$ & POLAND & $1997-99$ \\
ECUADOR & $1993-01$ & ROMANIA & $1999-01$ \\
EL SALVADOR & $1995-96$ & SPAIN & $1992-93$ \\
FINLAND & $1992-94$ & SRI LANKA & 1996 \\
FRANCE & $1994-95$ & SWEDEN & $1991-92$ \\
GHANA & $1997-01$ & TAIWAN & $1995,1997-98$ \\
GUATEMALA & $1992-99$ & TANZANIA & $1995-01$ \\
GUYANA & $1998-99$ & THAILAND & $1997-01$ \\
HONDURAS & $1993-01$ & TURKEY & $1994,2000-01$ \\
HONG KONG & 1998 & UK & $1990-99$ \\
HUNGARY & 1995 & UKRAINE & $1997-00$ \\
INDIA & $1991,1993-01$ & VENEZUELA & $1994-98$ \\
INDONESIA & $1994,1997-01$ & VIETNAM & $1996-01$ \\
ITALY & $1990-95$ & ZIMBABWE & $1996-01$ \\
JAMAICA & $1994-00$ & &
\end{tabular}


Table 3: Year of Initial Electricity Reform

\begin{tabular}{llll} 
Country & Year & Country & Year \\
\hline Antigua and Barbuda & 1975 & Japan & 1999 \\
Argentina & 1991 & Kazakhstan & 1996 \\
Australia & 1996 & Kenya & 1997 \\
Austria & 1999 & Korea, Rep. & 1966 \\
Bahamas, The & 1999 & Lao PDR & 1998 \\
Bangladesh & 1966 & Luxembourg & 1999 \\
Barbados & 1982 & Malaysia & 1992 \\
Belgium & 1999 & Mali & 1982 \\
Belize & 1992 & Mexico & 1995 \\
Bolivia & 1994 & Morocco & 1972 \\
Brazil & 1995 & Nepal & 1973 \\
Chile & 1978 & Netherlands & 1998 \\
China & 1987 & New Zealand & 1986 \\
Colombia & 1992 & Nicaragua & 1994 \\
Costa Rica & 1993 & Norway & 1991 \\
Cote d'Ivoire & 1997 & Oman & 1967 \\
Croatia & 1999 & Pakistan & 1997 \\
Czech Republic & 1992 & Panama & 1997 \\
Denmark & 1961 & Peru & 1992 \\
Dominica & 1997 & Philippines & 1987 \\
Dominican Republic & 1999 & Poland & 1997 \\
Ecuador & 1997 & Portugal & 1997 \\
El Salvador & 1995 & Romania & 1998 \\
Fiji & 1999 & Saudi Arabia & 1999 \\
Finland & 1995 & Senegal & 1983 \\
France & 1999 & Singapore & 1995 \\
Germany & 1999 & Spain & 1988 \\
Ghana & 1997 & Sri Lanka & 1977 \\
Guatemala & 1996 & Sweden & 1966 \\
Guyana & 1969 & Tanzania & 1999 \\
Honduras & 1991 & Thailand & 1995 \\
Hong Kong, China & 1999 & Trinidad and Tobago & 1994 \\
Hungary & 1994 & Tunisia & 1963 \\
India & 1998 & Turkey & 1997 \\
Indonesia & 1999 & Ukraine & 1980 \\
Ireland & 1993 & United Arab Emirates & 1998 \\
Israel & 1996 & United Kingdom & 1990 \\
Italy & 1996 & Vietnam & 1963 \\
Jamaica & & Zimbabwe & 1996
\end{tabular}


Table 4: Average Political Constraints (POLCON) Score by Country

\begin{tabular}{|c|c|c|c|}
\hline Country & POLCON & Country & POLCON \\
\hline Argentina & 0.74 & Laos & 0.00 \\
\hline Australia & 0.86 & Luxembourg & 0.77 \\
\hline Austria & 0.73 & Malaysia & 0.75 \\
\hline Bangladesh & 0.39 & Mali & 0.24 \\
\hline Belgium & 0.89 & Mexico & 0.37 \\
\hline Bolivia & 0.58 & Morocco & 0.41 \\
\hline Brazil & 0.69 & Myanmar (Burma) & 0.00 \\
\hline Cambodia & 0.00 & Nepal & 0.41 \\
\hline Chile & 0.77 & Netherlands & 0.73 \\
\hline China & 0.00 & New Zealand & 0.75 \\
\hline Colombia & 0.40 & Nicaragua & 0.75 \\
\hline Costa Rica & 0.74 & Norway & 0.77 \\
\hline Croatia & 0.42 & Oman & 0.00 \\
\hline Czech Republic & 0.74 & Pakistan & 0.32 \\
\hline Denmark & 0.77 & Panama & 0.50 \\
\hline Dominican Rep & 0.70 & Peru & 0.43 \\
\hline Ecuador & 0.73 & Philippines & 0.71 \\
\hline Egypt & 0.00 & Poland & 0.72 \\
\hline El Salvador & 0.43 & Portugal & 0.74 \\
\hline Fiji & 0.67 & Romania & 0.73 \\
\hline Finland & 0.77 & Saudi Arabia & 0.00 \\
\hline France & 0.73 & Senegal & 0.44 \\
\hline Germany & 0.84 & Singapore & 0.51 \\
\hline Ghana & 0.05 & Spain & 0.74 \\
\hline Guatemala & 0.36 & Sri Lanka & 0.49 \\
\hline Guyana & 0.73 & Sweden & 0.76 \\
\hline Honduras & 0.31 & Taiwan & 0.73 \\
\hline Hungary & 0.76 & Tanzania & 0.46 \\
\hline India & 0.73 & Thailand & 0.76 \\
\hline Indonesia & 0.15 & Trinidad & 0.86 \\
\hline Ireland & 0.75 & Tunisia & 0.32 \\
\hline Israel & 0.78 & Turkey & 0.76 \\
\hline Italy & 0.77 & UAE & 0.00 \\
\hline Ivory Coast & 0.07 & Ukraine & 0.55 \\
\hline Jamaica & 0.18 & United Kingdom & 0.73 \\
\hline Japan & 0.76 & Venezuela & 0.44 \\
\hline Kazakhstan & 0.00 & Vietnam & 0.00 \\
\hline Kenya & 0.60 & Zimbabwe & 0.51 \\
\hline Korea, South & 0.71 & & \\
\hline
\end{tabular}




\section{Table 5: Descriptive Statistics and Correlation Matrix}

Descriptive Statistics

Mean

Std. Dev.

Minimum

Maximum

\section{Correlation Matrix}

Dependent Variable: Policy Change or Dispute

Dependent Variable: Policy Change

Dependent Variable: Dispute

Multilateral Influence on Reform Adoption

Multilateral Influence $X$ Crisis (mean-centered)

Multilateral Influence $X$ Vintage (mean-centered)

Multilateral Influence X Political Constraints (mean-centered)

Equity-Weighted Host Country Experience of Investor Coalition

\section{Crisis}

Vintage of Emergent Institutions

Political Constraints

Per Capita Gross National Income (logged)

Megawatts (logged)
(2) (3)

$\begin{array}{lll}6452 & 6452 & 6452\end{array}$

$\begin{array}{lll}0.124 & 0.082 & 0.065\end{array}$

$\begin{array}{lll}0.330 & 0.275 & 0.247\end{array}$

$\begin{array}{lll}0.000 & 0.000 & 0.000\end{array}$

$\begin{array}{lll}1.000 & 1.000 \quad 1.000\end{array}$
(4)
(5)

(6) (7)

(8)

(9)

(10)

(11)

(12)

$\begin{array}{llllllllll}6452 & 6452 & 6452 & 6414 & 6335 & 6452 & 6452 & 6414 & 6362 & 6366\end{array}$

$\begin{array}{lllllllllll}-0.396 & -0.090 & 0.572 & -0.042 & 8.516 & 0.516 & 3.241 & 0.576 & 8.827 & 4.893\end{array}$

$\begin{array}{rrrrrrrrrrr}1.399 & 1.193 & 4.427 & 0.246 & 10.744 & 0.500 & 5.500 & 0.293 & 0.901 & 1.410\end{array}$

$\begin{array}{lllllllllll}-9.000 & -8.603 & -7.937 & -0.756 & 0.000 & 0.000 & 0.000 & 0.000 & 6.087 & 2.303\end{array}$

$\begin{array}{llllllllll}6.000 & 6.396 & 27.884 & 1.858 & 77.000 & 1.000 & 38.000 & 0.890 & 10.791 & 8.510\end{array}$

(1)

(2) 0.811

(3) $\quad 0.691 \quad 0.282$

(4) $\quad-0.039 \quad-0.052 \quad 0.018$

(5) $\quad \begin{array}{llll}-0.001 & 0.001 & 0.011 & 0.853\end{array}$

$\begin{array}{llllll}\text { (6) } & -0.034 & -0.040 & -0.022 & -0.309 & -0.412\end{array}$

$\begin{array}{lllllll}\text { (7) } & -0.104 & -0.130 & -0.051 & 0.272 & 0.447 & -0.194\end{array}$

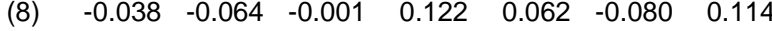

$\begin{array}{lllllllll}\text { (9) } & 0.116 & 0.109 & 0.037 & -0.125 & -0.075 & 0.030 & -0.190 & -0.170\end{array}$

$\begin{array}{lrrrrrrrrr}\text { (10) } & -0.114 & -0.126 & -0.058 & 0.080 & 0.060 & 0.521 & 0.043 & -0.100 & 0.079\end{array}$

$\begin{array}{lllllllllll}\text { (11) } & -0.019 & -0.047 & -0.044 & -0.104 & -0.132 & 0.043 & 0.320 & 0.127 & 0.066 & -0.081\end{array}$

$\begin{array}{llllllllllll}\text { (12) } & -0.187 & -0.184 & -0.151 & 0.127 & 0.086 & -0.060 & 0.039 & 0.320 & -0.332 & -0.010 & 0.530\end{array}$

$\begin{array}{llllllllllllll}\text { (13) } & 0.197 & 0.176 & 0.119 & -0.040 & -0.039 & 0.026 & -0.037 & 0.017 & 0.013 & 0.016 & -0.084 & 0.026\end{array}$ 


\section{Table 6: Econometric Analysis of the Incidence of Policy Changes and Disputes}

Multilateral Influence on Reform Adoption ( $\mathrm{H} 1>0)$

Multilateral Influence $X$ Crisis $(\mathrm{H} 2>0)$

Multilateral Influence X Vintage $(\mathrm{H} 3<0)$

Multilateral Influence X Political Constraints $(\mathrm{H} 4<0)$

Equity-Weighted Host Country Experience of Investor Coalition $(\mathrm{H} 5<0)$

Crisis

Vintage of Emergent Institutions

Political Constraints

Per Capita Gross National Income (logged)

Megawatts (logged)

\section{Constant}

$\rho$ (logged)

Sample

Number of Observations

Number of Plants

Number of Events (dependent variable=1)

Log Likelihood
(1)

(2)

0.084

0.847

0.555

0.002

$-0.068$

0.421

$-5.799$

0.022

$-0.099$

0.028

0.195

0.596

0.002

0.959

2.900

0.069

$-0.698$

0.003

0.554

0.000

$-2.651$

0.185

0.367

0.000

$$
\begin{array}{r}
\text { all } \\
5551 \\
1001
\end{array}
$$

187

$-538.08$
0.544

0.027

$-0.251$

0.158

$-0.183$

0.000

$-6.835$

0.001

$-0.147$

0.021

$-0.046$

0.536

2.634

0.092

$-0.556$

0.074

0.560

0.000

$-3.233$

0.182

0.410

0.000

0.078

0.008

$-2.832$

0.000

$-0.049$

0.134

$-0.010$

0.796

1.808

0.082

$-0.873$

0.009

0.598

0.000

$-1.044$

0.673

0.378

0.000

$$
\begin{array}{r}
\text { crisis } \\
2827 \\
749 \\
125 \\
-331.56
\end{array}
$$

non-crisis

2724

734

62

$-183.62$ 
Table 7: Hazard Rate Multipliers for High Multilateral-Influence on Reforms at Various Levels of Political Constraints, Crisis, Vintage and Investor Experience

Investor Coalition with Low Experience in Host Country

Crisis Year

\begin{tabular}{rrrrr}
\cline { 3 - 5 } & & Mean - 1SD & Mean & Mean + 1SD \\
vintage & Mean - 1SD & 88885.5 & 5382.2 & 325.9 \\
\cline { 3 - 5 } & Mean & 50072.3 & 3032.0 & 183.6 \\
Mean + 1SD & 31912.5 & 1932.4 & 117.0
\end{tabular}

Non-crisis Year

Political Constraints

\begin{tabular}{rrrrr}
\cline { 3 - 5 } vintage & low & Mean & high \\
\cline { 3 - 4 } & Mean - 1SD & 2.5 & 0.8 & 0.2 \\
\cline { 3 - 4 } & Mean & 3.2 & 1.0 & 0.3 \\
Mean + 1SD & 3.9 & 1.2 & 0.4
\end{tabular}

Investor Coalition with Mean Experience in Host Country

Crisis Year

Political Constraints

\begin{tabular}{rrrrr}
\cline { 3 - 5 } & & low & Mean & high \\
\multirow{2}{*}{ vintage } & Mean - 1SD & 29443.1 & 1782.8 & 108.0 \\
& Mean & 16586.3 & 1004.3 & 60.8 \\
\cline { 2 - 5 } & Mean + 1SD & 10571.0 & 640.1 & 38.8
\end{tabular}

Non-crisis Year

Political Constraints

\begin{tabular}{rrrrr}
\cline { 3 - 5 } vintage & low & Mean & high \\
\cline { 3 - 5 } & Mean - 1SD & 2.5 & 0.8 & 0.2 \\
& Mean & 3.2 & 1.0 & 0.3 \\
Mean + 1SD & 3.9 & 1.2 & 0.4
\end{tabular}

Investor Coalition with High Experience in Host Country

Crisis Year

Political Constraints

\begin{tabular}{lrrrr} 
& & low & Mean & high \\
\cline { 3 - 5 } vintage & Mean - 1SD & 6068.4 & 367.5 & 22.3 \\
\cline { 3 - 5 } & Mean & 3418.5 & 207.0 & 12.5 \\
\cline { 3 - 5 } & Mean + 1SD & 2178.7 & 131.9 & 8.0
\end{tabular}

Non-crisis Year

Political Constraints

\begin{tabular}{rrrrr} 
& & low & Mean & high \\
\multirow{2}{*}{ vintage } & Mean - 1SD & 2.5 & 0.8 & 0.2 \\
& Mean & 3.2 & 1.0 & 0.3 \\
\cline { 2 - 3 } Mean + 1SD & 3.9 & 1.2 & 0.4
\end{tabular}


Table 8: Top Ten Predicted Hazards for 1999-2001 that Did Not Encounter Policy Change or Dispute During Sample Period

\begin{tabular}{|c|c|c|c|c|}
\hline country & fname & $\frac{\text { year of }}{\text { investment }}$ & $\frac{\frac{\text { year of }}{\text { (expected) }}}{\text { operation }}$ & Notes on any reported resistance \\
\hline BRAZIL & $\begin{array}{l}\text { MACHADINHO DAM/ } \\
\text { SMELTER PROJECT }\end{array}$ & 1996 & 2003 & $\begin{array}{l}\text { 2001: } 1,500 \text { protesters occupy Ministry of Mines and Energy and picket Inter-American Development Bank } \\
\text { protesting forced resettlement to make way for hydroelectric power facility. Continued regulatory uncertainty } \\
\text { combined with a drought that leaves Machidno plant inoperable for } 20 \text { days leads to suspension by Tractebel of }\end{array}$ \\
\hline BRAZIL & $\begin{array}{l}\text { ELETROSUL } \\
\text { PRIVATIZATION - } \\
\text { GERASUL }\end{array}$ & 1998 & 1998 & $\begin{array}{l}\text { 2002: Suspension and redesign of regulatory reforms after power crisis triggered by } 2001 \text { drought; Tractebel } \\
\text { suspends all new investment in Gerasul. }\end{array}$ \\
\hline PHILIPPINES & $\begin{array}{l}\text { ILIJAN POWER } \\
\text { PROJECT }\end{array}$ & 1999 & 2002 & $\begin{array}{l}\text { 2002: Mirant and Philippine government dispute rationale for delay of opening of Ilijan power plant. Mirant claims } \\
\text { new President's review of all government contracts signed by Estrada led to delay whereas government focuses } \\
\text { on subsequent technical glitches. }\end{array}$ \\
\hline PAKISTAN & $\begin{array}{l}\text { JIO BAGGA POWER } \\
\text { PLANT }\end{array}$ & 1995 & 1998 & $\mathrm{n} / \mathrm{a}$ \\
\hline THAILAND & $\begin{array}{l}\text { SIAM POWER } \\
\text { (SIPCO) /SSP IND. } \\
\text { ESTATE }\end{array}$ & 1997 & $?$ & $\begin{array}{l}\text { 2003: Japanese creditors engaged in dispute with Thai courts regarding interpretation of Thai bankruptcy law in } \\
2000 \text { payment from Siam Strip Mill to Siam Power; allegations that court is favoring Thai over Japanese interests }\end{array}$ \\
\hline TURKEY & $\begin{array}{l}\text { MARMARA POWER } \\
\text { PLANT }\end{array}$ & 1996 & 1999 & $\mathrm{n} / \mathrm{a}$ \\
\hline INDIA & $\begin{array}{l}\text { ISPAT STEEL } \\
\text { WORKS } \\
\text { PROJECT/BHADRAV }\end{array}$ & 1999 & 2002 & $\begin{array}{l}\text { Plant still not built due to ongoing disputes over guarantees for payment for electricity from bankrupt or insolvent } \\
\text { state electricity boards }\end{array}$ \\
\hline INDIA & $\begin{array}{l}\text { VEMBAR LNG } \\
\text { POWER PLANT }\end{array}$ & 1998 & 2002 & $\begin{array}{l}\text { 2003: Government fails to implement } 1997 \text { agreement raising gas prices to competitive levels leading to lack of } \\
\text { development of new gas fields, shortages of gas, and delays in gas fired power plants such as Vembar LNG. }\end{array}$ \\
\hline BRAZIL & $\begin{array}{l}\text { USINA } \\
\text { HIDRELETRICA DE } \\
\text { ITA/ INDUST. POWER }\end{array}$ & 1995 & 2000 & $\begin{array}{l}350 \text { protestors occupy Brazilian headquarters of Tractebel protesting resttlement policies of villagers in dams } \\
\text { including Ita. Continued regulatory uncertainty combined with a drought that leaves Ita operating at } 15 \% \text { of } \\
\text { capacity leads to suspension by Tractebl of new projects in } 2003 \text {. }\end{array}$ \\
\hline INDIA & $\begin{array}{l}\text { KORBA WEST } \\
\text { POWER PLANT }\end{array}$ & 1999 & $?$ & $\begin{array}{l}\text { Plant still not built due to ongoing disputes over guarantees for payment for electricity from bankrupt or insolvent } \\
\text { state electricity boards }\end{array}$ \\
\hline
\end{tabular}




\section{Table 9: Econometric Analysis of the Incidence of Policy Changes and Disputes, Disaggregated Dependent Variable}

Dependent Variable $=$ Policy Change

Multilateral Influence on Reform Adoption ( $\mathrm{H} 1>0)$

Multilateral Influence X Crisis $(\mathrm{H} 2>0)$

Multilateral Influence $X$ Vintage $(\mathrm{H} 3<0)$

Multilateral Influence X Political Constraints $(\mathrm{H} 4<0)$

Equity-Weighted Host Country Experience of Investor Coalition ( $\mathrm{H} 5<0)$

Crisis

Vintage of Emergent Institutions

Political Constraints

Per Capita Gross National Income (logged)

Megawatts (logged)

Constant

(logged)

Sample

Number of Observations

Number of Plants

Number of Events (dependent variable=1)

Log Likelihood
(1)

$$
\text { (2) }
$$$$
-0.25
$$$$
0.541
$$$$
0.938
$$$$
0.000
$$

$-0.250$

0.000

$-9.078$

0.000

$-0.184$

0.013

0.877

0.104

$-0.133$

0.076

2.583

0.095

$-0.347$

0.256

0.602

0.000

$-6.876$

0.010

0.436

0.000

$$
\begin{array}{r}
\text { all } \\
5727 \\
1001
\end{array}
$$

124
1001

$-337.05$

\subsection{1}

0.021

$-0.348$

0.339

$-0.286$

0.000

$-9.498$

0.000

$-0.195$

0.001

$-0.140$

0.119

2.331

0.138

$-0.279$

0.519

0.559

0.000

$-5.843$

0.127

0.417

0.000

crisis non-crisis

2937

751

86

$-230.23$
Dependent Variable $=$ Dispute

$\begin{array}{ccc}1.468 & 0.868 & 0.191 \\ 0.020 & 0.027 & 0.402 \\ -0.506 & & \\ 0.197 & & \\ 0.021 & -0.079 & 0.000 \\ 0.639 & 0.283 & 0.993 \\ -6.773 & -7.011 & -0.185 \\ 0.053 & 0.020 & 0.864 \\ -0.068 & -0.139 & -0.029 \\ 0.094 & 0.098 & 0.206 \\ -0.070 & & \\ 0.849 & & \\ 0.031 & 0.016 & 0.039 \\ 0.191 & 0.772 & 0.192 \\ 3.777 & 3.768 & 0.791 \\ 0.008 & 0.003 & 0.545 \\ -1.010 & -1.116 & -0.843 \\ 0.000 & 0.023 & 0.023 \\ 0.481 & 0.491 & 0.477 \\ 0.000 & 0.000 & 0.010 \\ -0.656 & -0.015 & -0.676 \\ 0.784 & 0.997 & 0.794 \\ 0.443 & 0.531 & 0.423 \\ 0.000 & 0.000 & 0.000\end{array}$

$\begin{array}{rrr}\text { all } & \text { crisis } & \text { non-crisis } \\ 5840 & 3056 & 2784 \\ 1001 & 770 & 738 \\ 102 & 68 & 34 \\ -347.41 & -210.06 & -130.38\end{array}$


Figure 1

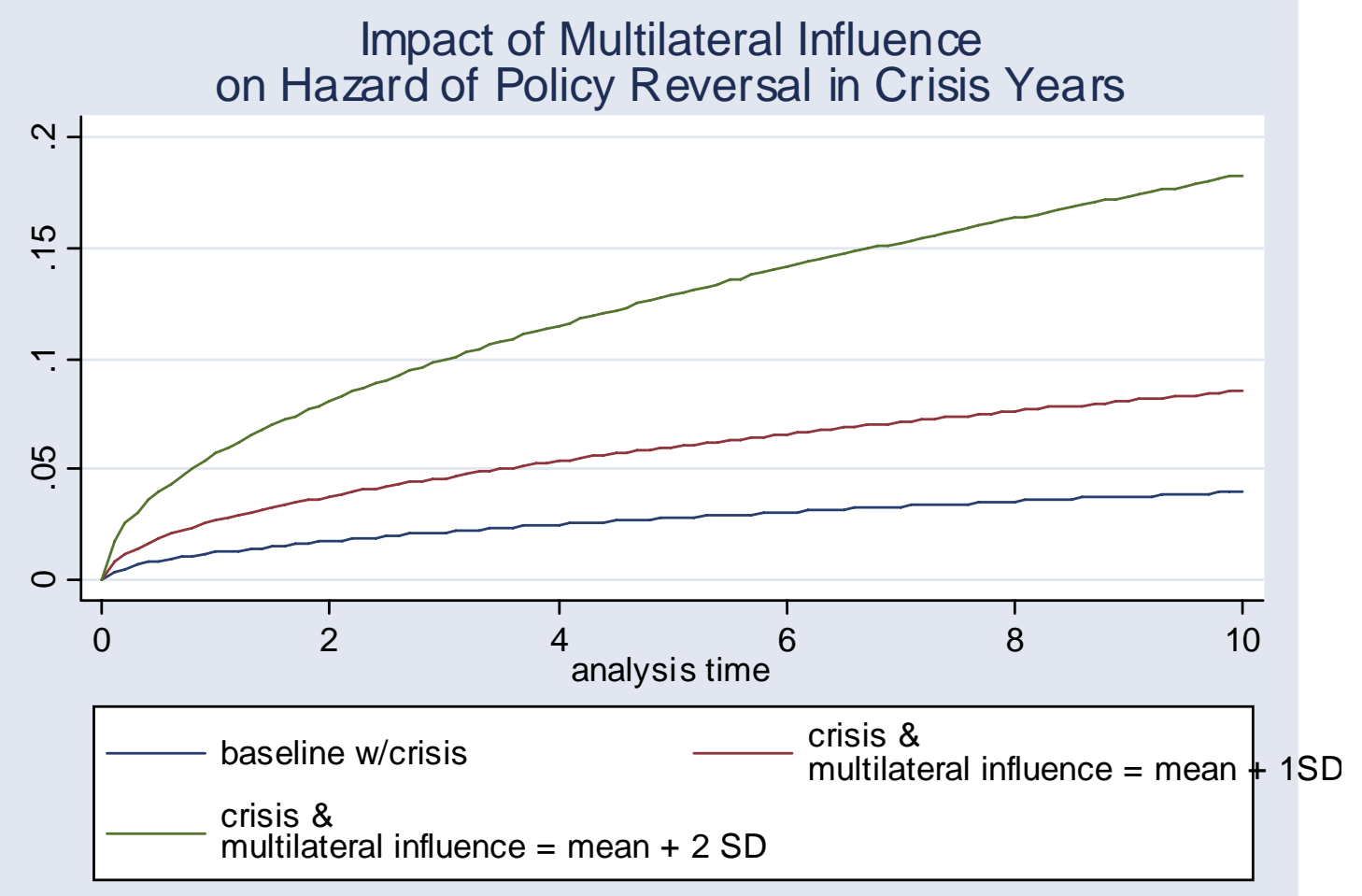

Figure 2

Impact of Multilateral Influence on Hazard of Policy Reversal

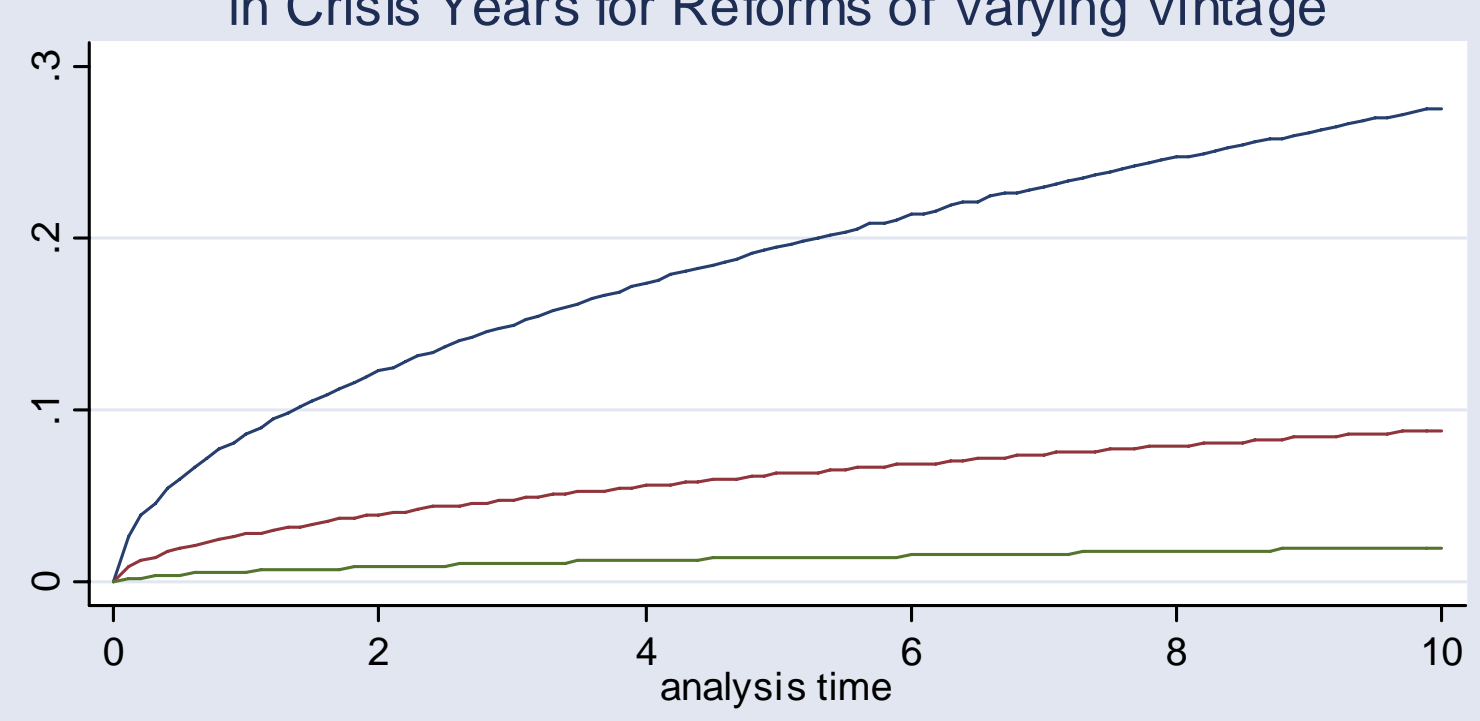

baseline $\mathrm{w} /$ crisis $\&$ vintage $=0$

crisis \& vintage $=$ mean $\&$

crisis \& vintage $=$ mean $+1 \mathrm{SD}$

multilateral influence $=$ mean $+1 S D$ 


\section{Figure 3}

Impact of Multilateral Influence on Hazard of Policy Reversal in Crisis Years with Varying Political Constraints

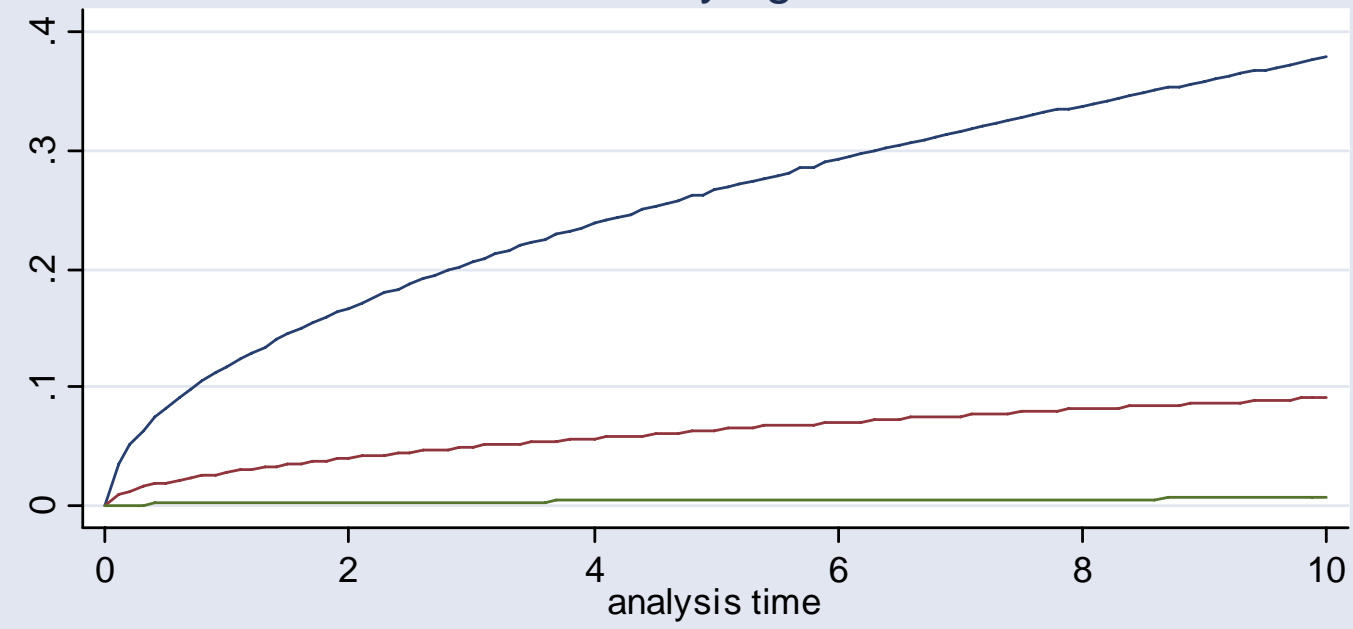

crisis \& polcon $=$ mean $-1 \mathrm{SD} \&$

crisis $\&$ polcon $=$ mean $\&$

multilateral influence $=$ mean $+\overline{1 S D}$ multilateral influence $=$ mean $+1 S D$

crisis \& polcon $=$ mean $+1 \mathrm{SD} \&$

multilateral influence $=$ mean $+1 \mathrm{SD}$

\section{Figure 4}

Impact of Multilateral Influence on Hazard of Policy Reversal in Crisis Years with Varying Investor Experience

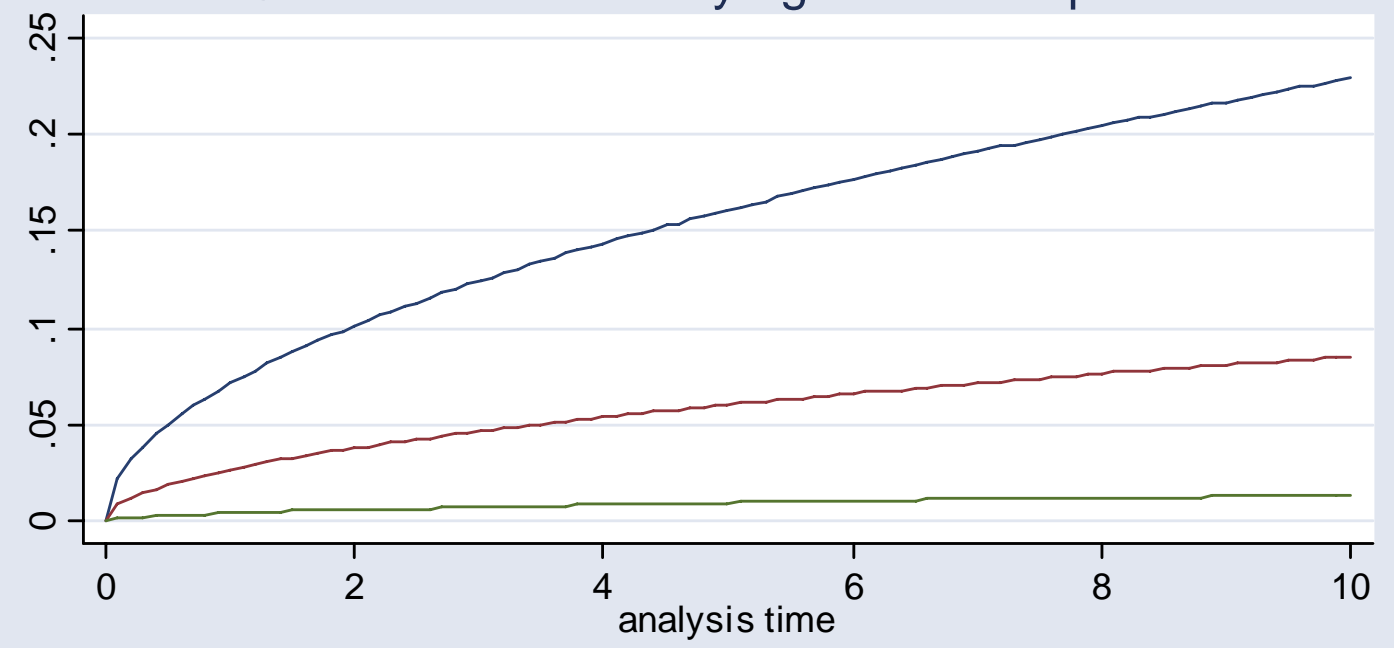

crisis \& experience $=$ mean -1 SD \& crisis \& experience $=$ mean \& multilateral influence $=$ mean $+\overline{1 S D}$ multilateral influence $=$ mean $+1 S D$ crisis \& experience $=$ mean $+1 \mathrm{SD} \&$ multilateral influence $=$ mean $+1 \mathrm{SD}$ 
